
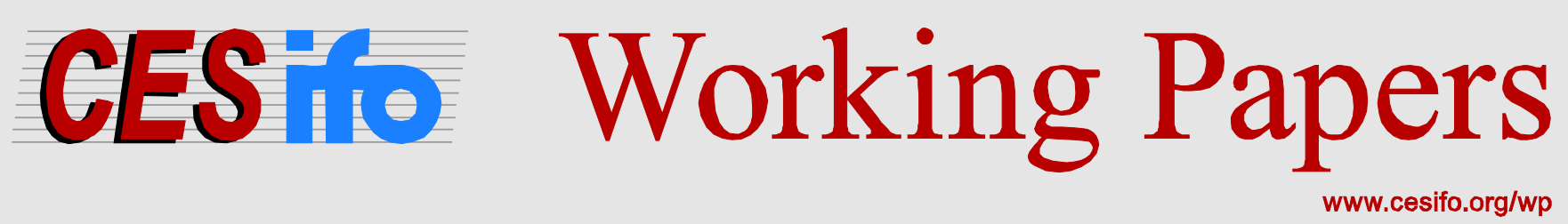

\title{
Nation Building: \\ The Role of Central Spending in Education
}

\author{
Francesco Cinnirella \\ Ruth Schueler
}

CESIFO WORKING PAPER NO. 6103

CATEGORY 5: ECONOMICS OF EDUCATION

SEPTEMBER 2016

An electronic version of the paper may be downloaded

- from the SSRN website:

- from the RePEc website:

- from the CESifo website: WwW.SSRN.com

Www.RePEc.org

www.CESifo-group.org/wp 


\title{
Nation Building: The Role of Central Spending in Education
}

\begin{abstract}
It is generally argued that, in the context of Imperial Germany, public primary education was used to form "loyal citizens" and to build a nation. In this paper we analyze to what extent central spending on primary education affected participation at general elections and votes for pro-nationalist parties. We combine census data on the sources of school funding with federal elec-tion data at the level of 199 constituencies in five-year intervals from 1886 to 1911. Panel esti-mates of models with constituency and time-fixed effects show that an increase in the share of central spending is positively related to the vote share of pro-nationalist parties and voter turnout. Results from models with lagged central spending by category of expenditure are consistent with the role of indoctrination of public primary education.
\end{abstract}

JEL-Codes: N330, N430, H720, I280.

Keywords: nation building, primary education, indoctrination, Prussian economic history.

Francesco Cinnirella

Ifo Institute - Leibniz Institute for Economic Research

at the University of Munich

Poschingerstrasse 5

Germany-81679 Munich

cinnirella@ifo.de
Ruth Schueler

Ifo Institute - Leibniz Institute for Economic Research

at the University of Munich

Poschingerstrasse 5

Germany - 81679 Munich

schueler@ifo.de

September 16, 2016

We are grateful to Davide Cantoni, Sybille Lehmann, Judith Saurer, Ludger Woessmann, and Noam Yuchtman and participants at the FRESH meeting in Barcelona and internal seminars at the Ifo Institute and at the University of Munich for their comments and suggestions. 


\section{$1 \quad$ Introduction}

There is a large literature which analyzes how the provision of public education depends on the extent of political voice (Lindert, 2004; Engerman et al., 2009; Go and Lindert, 2010; Chaudhary et al., 2012; Aidt et al., 2006; Gallego, 2010). Yet, quantitative research on the role of public education in forming political preferences and shaping electoral outcomes has received little attention in economic history. The question we address in this paper is: Does public spending on primary education buy votes, measured in terms of voter turnout and the share of pro-nationalist vote?

The majority of the literature on pork-barrel spending, that is, using government funds for local projects in order to "buy votes", looks at the impact of different kinds of investments on voter turnout or support for the incumbent party. In this paper, we are interested in the composition of public spending for primary education and its impact on electoral outcomes in Prussia between the nineteenth and the twentieth century. Whereas the previous literature looks at overall government funds, we are interested in examining whether the composition of public spending on education mattered, namely, whether funds came from local or central government. We argue that, in the context of Prussia after the German unification, the share of central funds captures the extent of the central state's control over the educational system which was instrumental to build a nation. In addition, as primary education was mostly financed through local funds until the late nineteenth-century, a shift to central funding, by alleviating the local finances, might have affected people's political preferences in favor of the incumbent nationalist government.

Prussia provides an interesting laboratory for testing the relationship between the composition of educational public spending and political preferences. The Prussian government increased the share of central spending on education from 10 to over 40 percent between 1886 and 1911 . At the same time, Prussia started using primary education to form Prussian citizens in order to create a homogeneous Prussian nation. In fact, central funds were often granted conditional on shifting the decisional power from local to central authorities. One example of conditioning central subsidies on decision-making power is the teacher recruitment law for the provinces of West Prussia and Posen. The law shifted teacher recruitment from local authorities to the central authorities, at the same time providing 2.6 million Marks for primary schools (Glück, 1979). This example clearly illustrates how higher central spending was related to higher control by the central state, assuring that the school curriculum matched that envisioned by the state authorities.

We exploit changes in central spending on primary education to examine whether the increasing impact of Prussian state authorities on educational affairs shaped political attitudes toward the central state, namely, voter turnout and support for pro-nationalist parties. Participating in elections was understood as one of a Prussian citizen's duties, allowing us to capture adherence to the 
central state. Imperial Chancellor Bismarck described the two conservative parties of the time (the Free Conservatives and the German Conservatives), along with the National Liberal Party, as parties that supported the Prussian state and its constitution, which is why the share of votes for those pro-nationalist parties in elections for the federal parliament, the Reichstag, allows measuring whether citizens aligned with the principles of the Prussian state.

We merge data on the federal elections of the German Empire with data on the composition of educational spending on primary schools stemming from six education censuses undertaken in Prussia between 1886 and 1911. Observing 199 constituencies at six different points in time allowed the construction of a dataset with nearly 1,200 observations. Beyond the distinction between central and local spending on education, the education censuses report also data on central spending for teachers and for school buildings, respectively. This distinction allows us to shed some light on the possible channels behind the relationship between central spending on education and electoral outcomes.

Using panel models with constituency-fixed effects we can account for unobserved timeinvariant characteristics of a constituency, such as persistently higher social capital when it comes to voter turnout, or a higher intensity of pro-nationalist attitudes in the past when it comes to support for pro-nationalist parties. Furthermore we investigate whether the impact of central education spending on electoral outcomes differs across subgroups, such as in constituencies with a large share of non-German speaking students, share of Catholics, share of blue-collar, in constituencies which are linguistically and religiously polarized, highly urbanized, and constituencies with a strong concentration of large landownership. Finally, by estimating a model with lagged independent variables we can test whether there is only a contemporaneous impact of central spending on education on electoral outcomes or whether spending on education affects also the future generations of voters. This analysis is particularly interesting as it informs about a possible "indoctrination effect" of teachers on students who later will become part of the electorate.

Our results suggest that an increase in the share of central spending on education leads to a higher vote share for pro-nationalist parties and slightly higher voter turnout. When decomposing the share of central spending into the shares devoted to teachers or to buildings, we find that both categories are positively related to the pro-nationalist vote share, with spending on teachers having a stronger effect. Instead no significant association is found between each category of central spending and voter turnout, suggesting that it is overall central spending that matters for voter turnout. 
Regarding effect heterogeneity, we find that increasing the share of central spending on education won support for pro-nationalist parties most notably from those segments of the population that traditionally opposed the Prussian ideal of a citizen, namely, non-German speaking and Catholic people, and from societies that were highly polarized in terms of their linguistic or religious composition.

Finally, estimates of the distributed lag model suggest that the share of pro-nationalist vote is strongly and significantly affected by the share of central spending on teachers 15 years earlier. This result is consistent with the interpretation that first-time voters have been "indoctrinated" by their teachers in primary school. Additionally, we find that pro-nationalist votes are affected by the contemporaneous share of central spending on buildings but also by spending on buildings of the previous 5 and 10 years.

The remainder of the paper is organized as follows. Section 2 discusses the related literature. Section 3 elaborates on the historical background. Section 4 introduces the dataset. Section 5 presents our baseline estimates with constituency and time fixed effects, the analysis by allocation of central spending, for subgroups, and with lagged central spending. Section 6 concludes.

\section{$2 \quad$ Related literature}

Our paper contributes to the vast literature on pork-barrel spending. The literature mainly focuses on the two-party U.S. electoral system. Whereas the majority of papers find evidence of pork barrel politics, almost none of the papers in this literature explicitly investigate the sources of government spending, and very few specifically look at spending on education. ${ }^{1}$ Voigtlaender and Voth (2014) look at the effect of highway construction in Nazi Germany on support for the NSDAP in the last semi-free elections after Hitler seized power. They argue that the infrastructure investment of building the highway signaled the state's interest in the region and thus bought votes for the NSDAP. As funding primary schools was widely perceived as a burden by municipalities and noble landlords, we similarly argue that investments in education that were made by the central state bought votes. Additionally, the construction of school buildings might have signaled the presence and the interest of the central state in the area.

Curto-Grau et al. (2014) investigate the pork barrel politics of road spending during the Spanish Restoration period, 1880-1914. They find that the regional allocation of funds for the construction of roads followed political factors, for instance the loyalty to the two-party alternation

\footnotetext{
${ }^{1}$ Calvo and Murillo (2004), Drazen and Eslava (2010), Engstrom and Vanberg (2010), Kwon (2005), Lazarus and Reilly (2010), Leigh (2008) Manacorda et al. (2011), Reynolds (2014) and Stratmann (2013) find evidence in favor of pork barrel spending influencing elections. Larcinese et al. (2015), Samuels (2002) and Treisman (1996) find no effect of government spending on electoral outcomes.
} 
system. Similarly, Cvrcek and Zajicek (2013) argue that the provision of primary education in the Habsburg Empire was politically and financially supported if the language of instruction corresponded to that of the dominant local elite.

Following the literature established by Lott (1990), we argue that education was used as a socialization tool. The main line of argumentation is that education produces both human capital and socialization (Gradstein and Justman, 2005; James, 1993; Lott, 1999; Pritchett and Viarengo, 2013). Valuing socialization, the state provides schooling. In his paper, Lott (1990) provides a theoretical model explaining why education is provided publicly even though private provision is much more efficient. As public schooling instills a common set of values and all government actions create wealth transfer, government-provided schooling is used to decrease the cost of wealth transfers as it allows controlling information, consequently inducing students to support certain transfers. In brief, schooling lowers the cost of wealth transfers by instilling the "right" views. Lott (1999) shows that totalitarian governments and governments with high transfers spend a lot on public education.

Specifically on indoctrination, Voigtländer and Voth (2015) show that Nazi indoctrination was highly effective: they show that cohorts that were exposed to anti-Semitic ideology in schools are today significantly more anti-Semitic than cohorts born before or after that period. Cantoni et al. (2014) study how changes in the school curriculum can shape students' political attitudes by examining a textbook reform in China that took place between 2004 and 2010. The new textbook was much more favorable toward the regime, which enhanced students' trust in government officials and changed their views on political participation and democracy.

Our paper contributes also to the economic-historical literature aimed at explaining voting patterns in historical Germany. Lehmann (2010) sheds light on why Imperial Germany, between the elections of 1878 and 1879, was one of the first countries in Europe to turn from liberalism to protectionism. Using King's algorithm, she attributes changes in votes to specific groups of voters and finds that the largest shift toward protectionism came from the agricultural sector, arguing that voting decisions depend on sectoral interests. In our paper, we similarly examine how electoral outcomes changed when different subgroups such as the noble landlords or Catholics were affected by an increasing share of central spending.

Koenig (2015) examines the effect of war participation on the rise of right-wing parties during the interwar period. By looking at electoral outcomes at the turn of the twentieth century and thereby at the formative years of the German nation, we shed light on a period in German history for which the historical literature's prior is that voting patterns followed the social milieu (Lepsius 1993), therefore implying a static distribution of votes. 
Finally, our paper has also a place in the large literature which shows that education increases political participation. Dee (2004) was the first to empirically show an effect of educational attainment on civic engagement and attitudes, exploiting child labor laws and the availability of higher education schools. The majority of papers investigating the relationship between education and political participation focus on democracies. The German Empire, however, was a constitutional monarchy. ${ }^{2}$ Consequently, the federal parliament, the Reichstag, had only limited power and votes in the Reichstag elections should be understood as a measure for the political preferences of the population. ${ }^{3}$

\section{$3 \quad$ Historical background}

The German Empire and Prussia, in particular, experienced several moments of "modernization" toward the turn of the century. Interest groups, such as large industrialists and large estate owners, achieved influence over political decisions. At the same time, the emerging power of the press led to the development of public opinion. ${ }^{4}$ Nationalism increased and the idea of an "ideal citizen" took root. The Prussian sense of identity had been "abstract and fragmentary" (Clark, 2007) before 1871, but the foundation of the German Empire in 1871 eventually led to a more defined national identity: being Prussian meant being Protestant and German. The duties of the Prussian citizenry consisted of voting, paying taxes, military service, school attendance, and respecting authorities. The army and the school were the newly founded Empire's most powerful integrating institutions and chiefly responsible for the burgeoning nationalism.

\subsection{The political system of Imperial Germany}

The German Empire was a constitutional monarchy under Prussia’s leadership. Even though the Reichstag was the first publicly elected parliament in German territory, it was the Emperor and the Imperial Chancellor who shaped the Empire's policy. The Reichstag's duties lay in approving the Empire's budget and enacting legislation. From the foundation of the German Empire in 1871

\footnotetext{
2 The historical literature is divided on how to categorize Imperial Germany in terms of its political system. Although it conducted some of the most democratic federal elections of the time, the impact of the Imperial Chancellor and the Emperor on legislation was clearly autocratic.

${ }^{3}$ In a similar context, Croke et al. (2015) test whether the relationship between education and political participation holds for a paradigmatic electoral authoritarian regime and formulate a disengagement hypothesis, expecting that education decreases political participation in a system where votes do not influence political decisions. Using a major educational reform in Zimbabwe that introduced variation in access to education, they find that education decreases political participation, giving credence to their hypothesis.

${ }^{4}$ Imperial Chancellor Bismarck explicitly used the press to shape people's preferences and beliefs. In 1882, he founded the semi-official organ Neueste Mittheilungen, which was clearly biased in favor of the government, though not an officially proclaimed organ of the government (Hoppe and Stöber, 2006).
} 
until his withdrawal in 1890, Imperial Chancellor Bismarck, who was simultaneously the Prime Minister of Prussia, shaped the interior policies of the German Empire and of Prussia. His post was not subject to the vagaries of popular election; he had the Emperor's complete trust. When Wilhelm II ascended the throne in 1888, Bismarck's and the Emperor's views on the future course of the German Empire diverged so widely in regard to both foreign affairs and how to solve the social question evolving from Prussia's transition to an industrial society, ${ }^{5}$ that Bismarck resigned his office in 1890. Wilhelm II involved himself much more actively in politics than his predecessors, sharply reducing the Imperial Chancellor's power, which is why his reign (18901914) is known as Wilhelminism. The waning power of the Imperial Chancellor allowed the Reichstag to gain more influence. And yet, as policy was chiefly set by the Imperial Chancellor or the Emperor, votes in the Reichstag elections can be understood as political preference measures.

The Reichstag was elected by the male population above age 25 in universal, free, and secret suffrage. Every male citizen over 25 hence had the right to vote in secret elections, each man having one vote. Elections were commonly held in schools and even though the constitution guaranteed secret voting, polling booths generally were not available until the turn of the century (Ullmann, 1980; Zippelius, 2006). The candidates were elected by an absolute majority voting system, which led to an increasing number of run-off ballots over time (Jesse, 2013). The 216 electoral constituencies were formed in 1871 and were designed to be of equal population size. However, despite huge internal migrations from the countryside to the cities and from the East to the West of the country, the constituencies were never redrawn, with the result that voters in the rural constituencies in the East were overrepresented. Figure 1 illustrates the political system of the German Empire as defined by its constitution.

The traditional historical narrative is that parties at the time lacked comprehensive party platforms and their electorates were constituted of the different social milieus that made up German society (Lepsius, 1993). There was the National Liberal Party (NLP) advocating the interests of the Grand Burghers and business magnates, who mainly supported Bismarck's policy. The Free Conservatives and the German Conservatives were, as the name indicates, conservative parties. The Free Conservative Party was mainly supported by conservative industrialists and had a big stronghold in the East Elbian Junkers. The Free Conservative Party supported both the policy of Imperial Chancellor Bismarck and the policy of Wilhelm II. The German Conservative Party equally represented the wealthy landowning elite Prussian Junkers and supported both Bismarck and successive chancellors. These three parties made up the pro-nationalist bloc of the party

\footnotetext{
${ }^{5}$ Even though Wilhelm II continued Bismarck's social reforms in improving the situation of workers, he did not use this policy to reduce the power of the worker's party, the Social Democratic Party (SPD), which was Bismarck's main concern in pursuing social reforms. He rather used the school as instrument against the SPD as explained below.
} 
spectrum with an electorate strongly mirroring the ideal Prussian citizen, that is, Protestant and German (Clark, 2007). Bismarck himself considered these parties as Reichsfreunde, so-called friends of the Empire (Hagen, 2002), and Johann von Miquel, leader of the National Liberal Party, stated that the "Free Conservatives and National Liberals are 'two middle parties', representing the mainstream of Protestant opinion" (Lamberti, 1989). Voting for one of these pro-nationalist parties demonstrated loyalty to the Prussian state.

Figure 1: The Political System of the German Empire

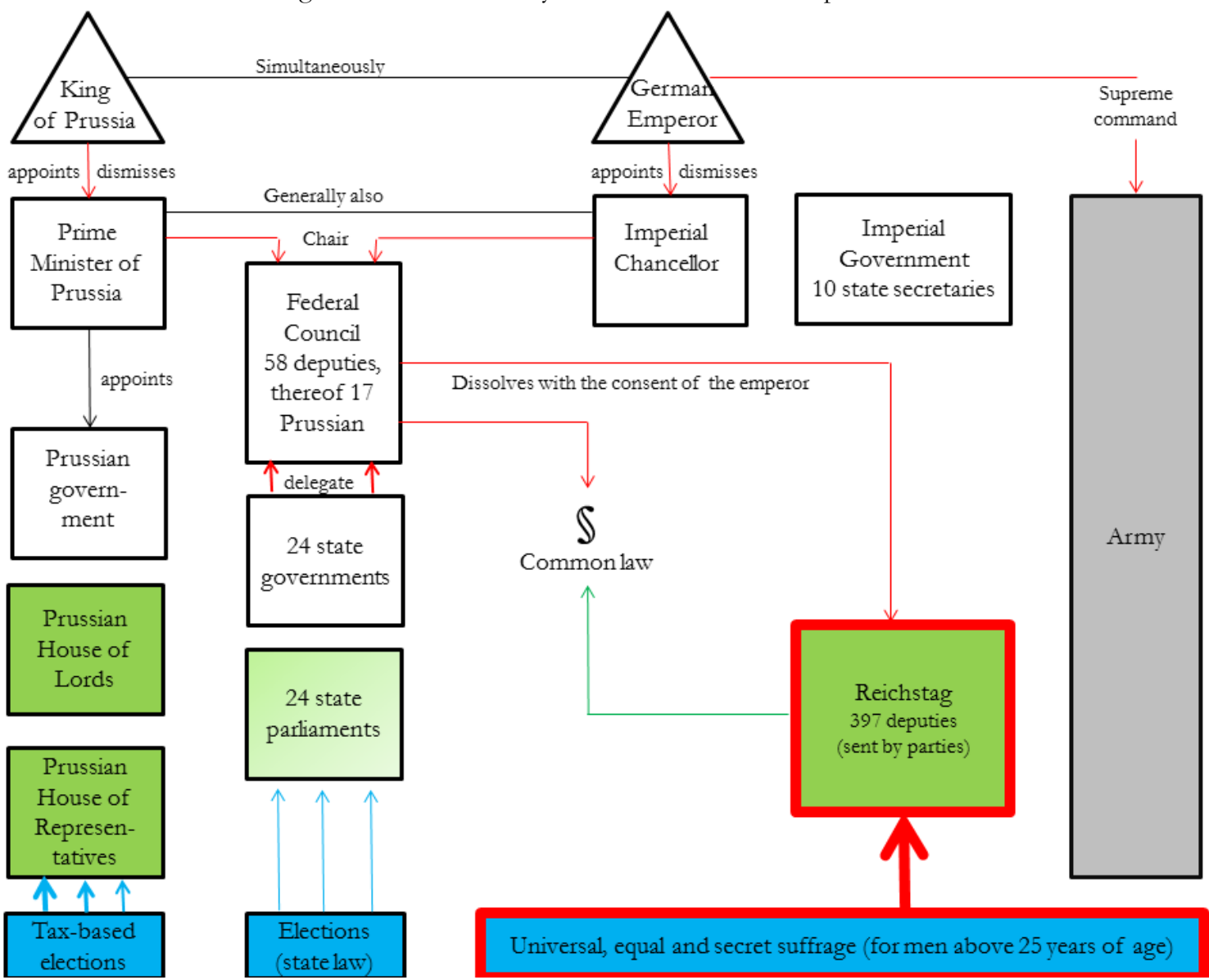

Source: Kochendörfer (1997, p. 127).

Opposed to the friends of the Empire there were the so-called Reichsfeinde-enemies of the Empire-whose electorate was made up of those who did not conform to the ideal Prussian citizen and advocated for policies different from those endorsed by the Imperial Chancellor or the Emperor. For example, there was the Center Party most of whose members and supporters were Catholic. Especially during the Kulturkampf, the cultural and political struggle between the Prussian authorities and the Catholic Church, the Center Party was depicted as an enemy within the Empire. Equally the Social Democratic Party (SPD) was strongly opposed by the traditional Prussian elite as they advocated for worker rights. Bismarck was vehemently opposed to the nascent 
social-democratic movement and even managed to ban the SPD between 1878 and 1890, meaning that Social Democrats could be elected only as list-free candidates. After the ban was lifted, the party quickly developed into a party of the masses and garnered the majority of votes in the Reichstag elections (Sperber, 1997).

Several smaller parties, such as the German Free-Minded Party and others that particularly advocated for minority rights, such as for the Poles or the Danes, were naturally excluded from the Prussian ideal (Sperber, 1997).

\subsection{The integrative function of the Prussian primary school}

Gradstein and Justman (2005) note that the Prussian educational system before foundation of the German Empire was characterized by incorporating minority schools within the public educational system as separate autonomous streams. Prior to 1871 , the educational system was clearly denominational; there were separate schools for Protestant and Catholic children, each operating under the supervision of its own clergy. With the foundation of the German Empire and enactment of the School Inspection Law in 1872, which mandated centralized school inspection in primarily Catholic counties, Catholic schools lost the authority to monitor themselves. ${ }^{6}$ At the same time, aggressive policy against the Poles, led by Imperial Chancellor Bismarck, banned Polish as a language of instruction in primary school (Lamberti, 1989). These laws illustrate how a common identity can be shaped through demarcation (Kühne, 1997).

Accompanying its increasing financial involvement in primary education, was the central state's declaration of the school as an instrument for enhancing Prussian virtues and molding Prussians into citizens who would fulfill their proper duties of voting, paying taxes, military service, school attendance, and respecting the authorities. Early on, in his royal decree of 1889 (Erlass Kaiser Wilhelms II. zur Reform des Schulunterrichts als Mittel zum Kampf gegen den Sozialismus, 1. Mai 1889), Wilhelm II stressed the role of education in building a common identity. This decree was clearly aimed against social democracy and introduced a curriculum favorable to the Prussian Kings. The decree stressed the function of the school to "generate a healthy perception of the federal and social conditions by enhancing godliness and the love of the country."

The General Regulations of 1872 introduced a national curriculum for all of Prussia. More than half the standardized curriculum was devoted to ideological subjects such as religion, German language, and history. The reader, the textbook used in Prussian elementary schools, ${ }^{7}$ stressed life in the community and encouraged patriotism (through so-called vaterländische Er-

\footnotetext{
${ }^{6}$ On the consequences of this reform, see (Schueler 2016).

7 The readers were approved by the Prussian Ministry of Ecclesiastical and Education Affairs and followed a standardized structure that included a selection of core texts common to all readers.
} 
ziehung) by allowing the various region-specific readers to use the particularities of each Prussian region to evoke a feeling of homeland (Heimat) (Kennedy 1997).

\subsection{The political economy of the Prussian primary school}

During the German Empire, politicians struggled for more than two decades to pass a comprehensive school law that would regulate the most important aspects of the educational system, not achieving this goal until 1906. The school law as finally enacted ensured a fair distribution of the financial obligations incurred by primary schools, granted free attendance at primary school, and guaranteed teachers a fair salary (Lamberti, 1989).

Prior to the enactment of this comprehensive, nationwide school law, school policy was decided by the local administration, the clerical school inspectors, primary school teachers, municipal authorities, school commissions and patrons (i.e. the landlords), and parents of school children, as well as by political parties. The political parties were especially influential due to their work on petitions and participation in the parliamentary discussions in regard to the school law (Kuhlemann, 1991).

The chief issues intended to be addressed by the school law were, first, who should pay for schools, second, who should have the authority over them, and third, what kind of education should be offered-religious or secular (Anderson, 1970). This latter issue mainly revolved around the possibility of interdenominational mixed schools (Simultanschulen) where Protestant and Catholic students were taught simultaneously.

The parties took positions on some or all of these issues. The conservative parties were chiefly interested in relieving the noble landowners from having to pay for primary schools. The National Liberal Party supported the introduction of interdenominational mixed schools and especially wanted to ensure central control over schools. The liberal parties were interested in modernizing the educational system by increasing investment in school maintenance and construction. They opposed the denominational orientation of the current religious education and advocated for a form of religious education in which Christianity would be given historic significance. Furthermore, the liberal parties were in favor of handicraft instruction for boys and instruction in domestic economy for girls. The Center Party strongly opposed the introduction of interdenominational mixed schools and fought for continuance of the denominationally divided educational system. The SPD advocated for secularization of the educational system, suggesting the introduction of comprehensive schools where all students would be taught together from kindergarten up to university. The SPD also wanted to ensure free attendance at primary school for everyone (Kuhlemann, 1991). 
Until the central state slowly expanded its involvement in the educational system, Prussian primary schools were mainly financed through local means. In Table 1 we examine the contributors to primary school funding in 1886, which was before the substantial shift to central funding took place, to investigate which segments of the population were especially burdened under the local regime and consequently benefited most from central state funding. In 1886, central state funding, comprised of central state grants and funds, made up only about 12 percent of total spending on primary schools. ${ }^{8}$ Primary schools were mostly financed by the patronage, which meant that the landed elite paid primary school expenses. One-quarter of total expenditures were covered by the landed elite, which included nearly 40 percent of teacher wages. Municipalities were also important contributors; they covered 23 percent of total school expenditures and their contribution amounted to 60 percent of building expenditures and 67 percent of maintenance expenditures. The responsibility of municipalities for the erection, maintenance, and enlargement of public primary schools was set out in Article 25 of the Imperial Constitution. Schooling societies were the third pillar of school finance. Schooling societies were comprised of the heads of economically independent households in a school constituency who were required to make contributions on basis of their property, regardless of whether the household had school-age children. Schooling societies funded 19 percent of total school expenditures, covering about onequarter of building and maintenance expenditures and a lesser amount of teacher wages. School fees, covering 11 percent of overall expenditures, played a non-negligible role in financing primary schools. School fees were exclusively devoted to teacher wages of which they covered 17 percent. The smallest contributors to school expenses were school foundations; they contributed 9 percent of total expenses, most of which went toward teacher wages. Contributions from foundations mainly meant contributions from church foundations, reflecting the historical tie between the Prussian educational system and the church. ${ }^{9}$

Toward the end of the nineteenth century, the central state became more heavily involved in financing Prussian primary schools. After passing a law in 1886 that granted sole authority to the central state to recruit teachers in the provinces of West Prussia and Posen, central state funding of primary school in these two provinces was supposed to increase substantially: 200,000 Mark were promised for school inspection; 400,000 Mark were to be provided for teacher wages; 2 million Mark were meant to be granted for construction of primary schools (Glück, 1979). ${ }^{10}$ Sev-

\footnotetext{
${ }^{8}$ This number is slightly higher than the one shown in Table 3 below because the unit of observation in Table 1 is the county, whereas in Table 3 it is the constituency.

${ }^{9}$ For a detailed description of the functioning of church foundations in Brandenburg, see Moderow (2007).

${ }^{10}$ As the law was fully enacted in 1887, data from the education census of 1891 allow setting these investments in perspective. With overall central state spending amounting to 27.7 million Mark, the funds associated with the teacher recruitment law amounted to 9 percent of total central spending in the two provinces.
} 
eral laws increasing central state funding of primary schools were passed at the end of the 1880s. A law of 1887 allowed for central state grants to rural municipalities and small towns through the Prussian Ministry of Ecclesiastical and Education Affairs and its associated bureaucracy (Kuhlemann, 1991). The first comprehensive law paving the way toward higher central state funding throughout the entire German Empire was passed in 1888/1889. This law fixed subventions for teacher salaries, abolished school fees, and relieved landlords of their burden to fund primary schools. Unsurprisingly, the two conservative parties had strongly supported this law, as the affected landlords made up the bulk of their electorate. In light of the fact that the landlords had also been the main contributors to teacher wages they benefited substantially from the passage of this law. In 1897, the teacher pay law (Diensteinkommensgesets) fixed a minimum wage that had to be paid to all Prussian teachers and simultaneously guaranteed funding of this basic teacher pay, again increasing the share of school funds stemming from central sources. The minimum wage was set at 900 Mark, ${ }^{11}$ with the possibility of achieving seniority pay in nine steps (Kuhlemann, 1991). Finally, the school law of 1906 created a uniform legal framework for central state funding (Lamberti 1989).

Table 1: Composition of educational spending in 1886

\begin{tabular}{lc|ccc}
\hline & $\begin{array}{c}\text { Total } \\
\text { expenditures }\end{array}$ & $\begin{array}{c}\text { Teacher } \\
\text { wages }\end{array}$ & $\begin{array}{c}\text { Building } \\
\text { expenditures }\end{array}$ & $\begin{array}{c}\text { Maintenance } \\
\text { expenditures }\end{array}$ \\
\hline Patronage & 0.25 & 0.39 & 0.04 & 0 \\
Municipality & 0.23 & 0 & 0.60 & 0.67 \\
Societies & 0.19 & 0.14 & 0.25 & 0.27 \\
School fees & 0.11 & 0.17 & 0 & 0 \\
Foundations & 0.09 & 0.13 & 0.03 & 0.03 \\
Other & 0.01 & 0 & 0.03 & 0.01 \\
\hline State grants & 0.11 & 0.15 & 0.05 & 0.02 \\
State funds & 0.01 & 0.01 & 0 & 0 \\
\hline
\end{tabular}

Source: Education census of 1886. Note: Data refer to 472 counties. All figures are in shares.

In addition to these mandated contributions from the central state, the local bureaucracy could lobby for more funding. In 1905, the head of the province of Posen, von Waldow, sent a detailed description of local primary school conditions and requested 30 million Marks for the construction and improvement of school buildings and the recruitment of 1,747 new teachers. He stressed that students' cultural advancement was suffering due to overcrowded classrooms and insufficient school buildings (Unruh, 1992).

11 Thereby teachers exactly pass the threshold of 900 Mark to pay income taxes. 


\section{$4 \quad$ Data}

Data on public spending on primary education stem from the education censuses taken every five years from 1886 to 1911. Data for 1886 are readily available through the ifo Prussian Economic History Database (Becker et al., 2014). The data from the education censuses of 1891 and 1896 have been digitized by Cinnirella and Schueler (2016). For this paper we have digitized the data from the education censuses of 1901 to 1911 . We merge the education data with election data on the first ballot cast by Prussian voters in elections for the German Reichstag in 1887, 1893, 1898, 1903, 1907, and 1912. ${ }^{12}$ The timing of the education censuses and the elections of the German Reichstag allow observing the political consequences of educational spending as illustrated in Figure 2.

Data on the elections of the German Reichstag are available for 216 constituencies that remained stable over the whole period under observation. As we merge data on the Reichstag elections with county-level data on spending, we have to aggregate county-level data at the constituency level. Most constituencies are made up of two to four counties. However, there are instances where a county belongs to two adjacent constituencies. In these cases, we merge the two constituencies into one, ending with 199 constituencies in the annual sample. Consequently, we observe 199 constituencies over six points in time, resulting in 1,194 observations.

Figure 2: Timeline of data on education census and Reichstag elections

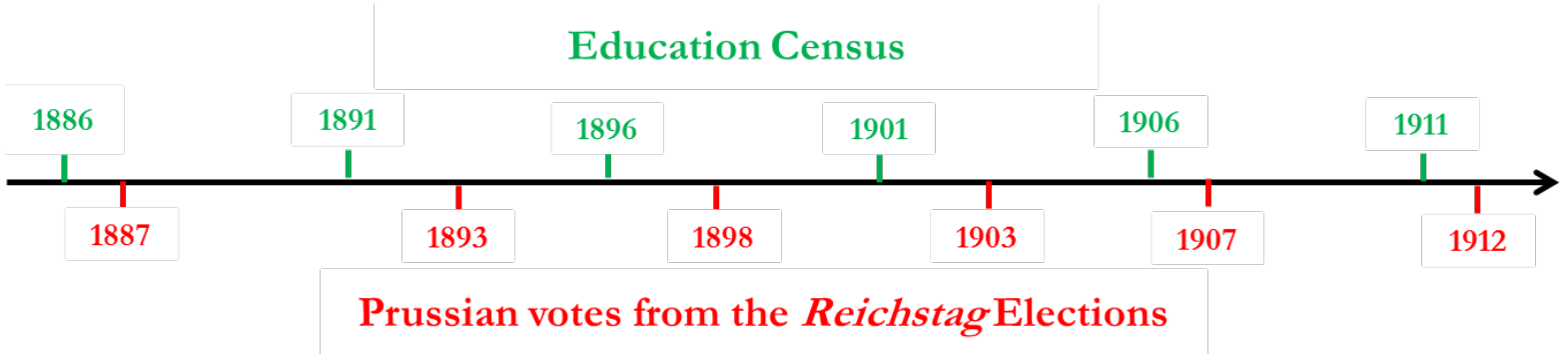

Note: Own illustration.

Our outcome variables are voter turnout and the share of pro-nationalist votes. We construct voter turnout by dividing the number of votes by the electorate. The share of pro-nationalist votes is constructed as the sum of the votes for the three pro-nationalist parties-the German Conservatives, the Free Conservatives, and the National Liberals-over the number of valid votes.

Crucial for our analysis, data from the education censuses allow disentangling primary school funds provided by the central state from those provided locally. Furthermore, these data allow

${ }^{12}$ Data on electoral outcomes stem from the Galloway Prussia Database (Galloway, 2007). 
discerning the allocation of funds, that is, whether it was spent for teachers or for building purposes.

We add data from the population censuses and the agricultural and vital statistics between 1885 and 1910 to generate control variables. ${ }^{13}$ We generate the share of people living in cities and the population density to control for the different interests and voting patterns of the urban population compared to those of the rural population. We control for the share of Protestants in the population as being Protestant conformed to the ideal Prussian citizen and we hence expect a high share of Protestants to increase participation in the elections and support for pro-nationalist parties. Along the same lines, we include the share of non-German-speaking students. The majority of non-German speakers were Poles, followed by other Slavs and Danes. Poles and other ethno-linguistic minorities longed for autonomy and therefore opposed the Prussian state. As the landed elite comprised the principal electorate of the pro-nationalist parties, we include landownership concentration in a constituency. ${ }^{14}$ We expect landownership concentration to be positively correlated with both voter turnout and the vote share for pro-nationalist parties. ${ }^{15}$ As the population working in manufacturing constituted the SPD's main electorate we consider the share of the population employed in manufacturing. ${ }^{16}$ Lastly, in the estimations on voter turnout we include a dummy variable for whether the constituency had a run-off ballot, called "swing constituency," as a robustness check. The variable takes the value 1 if no party reached a share above 50 percent in the first round of elections and 0 otherwise. We expect that close elections, captured by the "swing constituency" dummy, increase voter turnout.

In the estimations of support for pro-nationalist parties we control for voter turnout because this constitutes a possible channel. Finally, we include a dummy variable for whether the constituency's delegate belonged to one of the pro-nationalist parties in the previous legislative period. This variable is constructed from the results for Reichstag elections published by the Imperial Statistical Office (1887-1912), which include the name and the party affiliation of each candidate winning the election in the respective constituency.

\footnotetext{
13 These variables are also from the Galloway Prussia Database (Galloway, 2007).

14 On how landownership concentration affects demand for education over the nineteenth century, see Cinnirella and Hornung (2016).

15 As data on landownership are nonexistent for 1891, 1901, and 1911, we linearly interpolate the data on landownership concentration for those years.

16 As for landownership concentration, the occupation census provides information on the share in manufacturing only for the years 1882, 1895, and 1907, which is why we interpolate the data for the years 1891, 1901, and 1911.
} 


\subsection{Descriptive statistics}

As Figure 3 illustrates, educational expenditures by the central state increased substantially between 1886 and 1911 with the increases being particularly high between 1886 and 1891 and between 1906 and 1911, consistent with the institutional changes described above. While primary school funding in 1886 was still chiefly local, central state expenditure increased after 1888/1889 with the so-called Schulunterhaltungsgesetr. The level of central state expenditure stayed stable over the period of 1891 to 1896 . An increase in central state expenditure is again observed after 1897 when the first teacher pay law (Diensteinkommensgesets) was introduced. Central state contributions were again stable over the period from 1901 to 1906. The last increase in central state expenditure occurred in 1911 - after the introduction of the first comprehensive school law for Prussia in 1906.

These institutional changes can also be observed when looking at the overall increases in the share of central state spending between different years, as shown in Table 2. The highest shift is observed between 1886 and 1891, with an overall increase in the share of central state spending of nearly 25 percentage points. After a short overall drop between 1891 and 1896, a slight increase is observed between 1896 and 1901 when the teacher pay law was introduced. After another slight decrease between 1901 and 1906, the comprehensive school law of 1906 results in an increase in the share of central state spending of 9 percentage points.

Descriptive statistics in Table 3 illustrate the secular increase in overall spending on primary schools over the period of 1886 to 1911 . The average expenditure per student doubled over the course of those 25 years-from 23 to 57 Mark per student.

Table 2: Differences in the share of central state spending between years

\begin{tabular}{lcccc}
\hline Difference between & Mean & Std. Dev. & Minimum & Maximum \\
\hline 1886-1891 & 0.246 & 0.061 & 0.074 & 0.362 \\
$1891-1896$ & -0.041 & 0.033 & -0.146 & 0.044 \\
$1896-1901$ & 0.027 & 0.055 & -0.116 & 0.196 \\
$1901-1906$ & -0.017 & 0.042 & -0.142 & 0.168 \\
$1906-1911$ & 0.093 & 0.061 & -0.045 & 0.318 \\
\hline $1886-1911$ & 0.062 & 0.115 & -0.146 & 0.362 \\
\hline
\end{tabular}

Note: Figures based on 199 constituencies.

However, there is also significant variation in the share of central state spending within each cross-section. As shown in Figure 3, the provinces of Posen, Prussia, and Pomerania see the highest shares of central state spending, whereas the Rhineland, Westphalia, and SchleswigHolstein receive the lowest share of central state spending over the whole period of observation. 
Figure 3: The share of central spending by province, 1886-1911

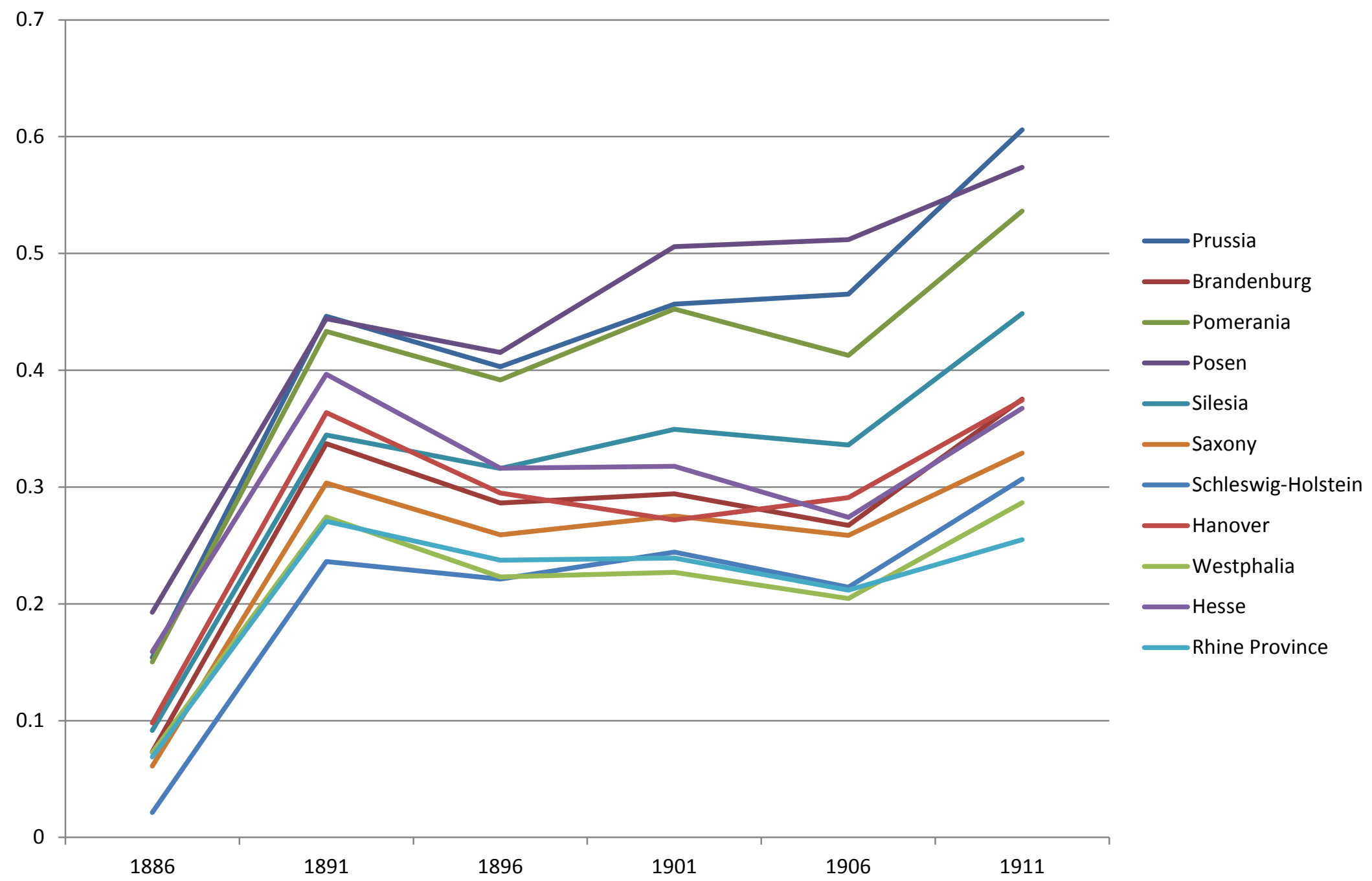

Note: As the province of Hohenzollern consists of only one constituency, we merge data on the provinces of Hohenzollern and Westphalia. See Appendix 3A for data sources and details. 
Table 3: Descriptive statistics

\begin{tabular}{|c|c|c|c|c|c|c|}
\hline & 1886 & 1891 & 1896 & 1901 & 1906 & 1911 \\
\hline \multirow[t]{2}{*}{ Voter turnout } & 0.77 & 0.72 & 0.68 & 0.75 & 0.85 & 0.84 \\
\hline & $(0.081)$ & $(0.075)$ & $(0.109)$ & $(0.084)$ & $(0.050)$ & $(0.056)$ \\
\hline \multirow[t]{2}{*}{ Pro-nationalist vote (share) } & 0.49 & 0.36 & 0.32 & 0.33 & 0.35 & 0.33 \\
\hline & $(0.251)$ & $(0.235)$ & $(0.229)$ & $(0.226)$ & $(0.246)$ & $(0.260)$ \\
\hline \multirow[t]{2}{*}{ Education spending per student (Marks) } & 22.58 & 27.45 & 32.63 & 41.67 & 45.56 & 57.48 \\
\hline & $(7.402)$ & $(7.242)$ & $(8.629)$ & $(14.007)$ & $(13.513)$ & $(12.662)$ \\
\hline \multirow[t]{2}{*}{ Spending on buildings per student (Marks) } & 3.51 & 3.78 & 5.39 & 6.37 & 6.08 & 8.41 \\
\hline & $(3.001)$ & $(2.353)$ & $(3.016)$ & $(7.150)$ & $(5.284)$ & $(5.880)$ \\
\hline \multirow[t]{2}{*}{ Spending on teachers per student (Marks) } & 19.06 & 23.68 & 27.24 & 35.30 & 39.48 & 49.08 \\
\hline & $(5.115)$ & $(5.828)$ & $(6.646)$ & $(8.741)$ & $(10.284)$ & $(12.078)$ \\
\hline \multirow[t]{2}{*}{ Central spending (share) } & 0.10 & 0.35 & 0.31 & 0.34 & 0.32 & 0.41 \\
\hline & $(0.074)$ & $(0.112)$ & $(0.105)$ & $(0.142)$ & $(0.146)$ & $(0.186)$ \\
\hline \multirow[t]{2}{*}{ Central spending on buildings (share) } & 0.06 & 0.07 & 0.05 & 0.19 & 0.21 & 0.18 \\
\hline & $(0.080)$ & $(0.084)$ & $(0.077)$ & $(0.191)$ & $(0.202)$ & $(0.187)$ \\
\hline \multirow[t]{2}{*}{ Central spending on teachers (share) } & 0.11 & 0.39 & 0.36 & 0.36 & 0.34 & 0.46 \\
\hline & $(0.078)$ & $(0.119)$ & $(0.114)$ & $(0.142)$ & $(0.146)$ & $(0.207)$ \\
\hline \multirow[t]{2}{*}{ Urbanization rate } & 0.32 & 0.33 & 0.34 & 0.35 & 0.36 & 0.37 \\
\hline & (0.197) & $(0.198)$ & (0.199) & $(0.201)$ & $(0.203)$ & $(0.206)$ \\
\hline \multirow[t]{2}{*}{ Population density } & 3.13 & 3.52 & 3.79 & 4.25 & 4.50 & 4.59 \\
\hline & $(15.775)$ & $(18.708)$ & (19.894) & $(22.409)$ & $(23.871)$ & $(24.126)$ \\
\hline \multirow[t]{2}{*}{ Protestant (share) } & 0.60 & 0.60 & 0.60 & 0.60 & 0.60 & 0.59 \\
\hline & $(0.366)$ & $(0.363)$ & $(0.362)$ & $(0.359)$ & $(0.356)$ & $(0.352)$ \\
\hline \multirow[t]{2}{*}{ Non-German students (share) } & 0.13 & 0.13 & 0.13 & 0.13 & 0.13 & 0.13 \\
\hline & $(0.255)$ & $(0.255)$ & $(0.258)$ & $(0.251)$ & $(0.248)$ & $(0.251)$ \\
\hline \multirow[t]{2}{*}{ Landownership concentration } & 0.01 & 0.02 & 0.03 & 0.03 & 0.02 & 0.03 \\
\hline & $(0.008)$ & $(0.025)$ & $(0.042)$ & $(0.033)$ & $(0.025)$ & $(0.044)$ \\
\hline \multirow[t]{2}{*}{ Employed in manufacturing (share) } & 0.12 & 0.13 & 0.13 & 0.14 & 0.15 & 0.21 \\
\hline & $(0.055)$ & $(0.058)$ & $(0.061)$ & $(0.065)$ & $(0.069)$ & $(0.122)$ \\
\hline \multirow[t]{2}{*}{ Swing constituencies (dummy) } & 0.16 & 0.39 & 0.19 & 0.42 & 0.38 & 0.46 \\
\hline & $(0.364)$ & $(0.489)$ & $(0.394)$ & $(0.495)$ & $(0.487)$ & $(0.500)$ \\
\hline \multirow[t]{2}{*}{ Pro-nationalist delegate (dummy) } & 0.45 & 0.55 & 0.43 & 0.39 & 0.40 & 0.42 \\
\hline & $(0.493)$ & $(0.493)$ & $(0.489)$ & $(0.480)$ & $(0.483)$ & $(0.490)$ \\
\hline \multirow[t]{2}{*}{ Linguistic polarization } & 0.20 & 0.20 & 0.20 & 0.21 & 0.21 & 0.22 \\
\hline & $(0.342)$ & $(0.341)$ & $(0.335)$ & $(0.335)$ & $(0.331)$ & $(0.327)$ \\
\hline \multirow[t]{2}{*}{ Religious polarization } & 0.42 & 0.43 & 0.44 & 0.45 & 0.46 & 0.47 \\
\hline & $(0.330)$ & $(0.327)$ & $(0.325)$ & $(0.320)$ & $(0.314)$ & $(0.309)$ \\
\hline
\end{tabular}

Note: Descriptive statistics of selected key variables for 199 constituencies. Standard deviation in parenthesis. See Appendix 3A for data sources and details. 
Figure 4: Voter turnout by province, 1887-1912

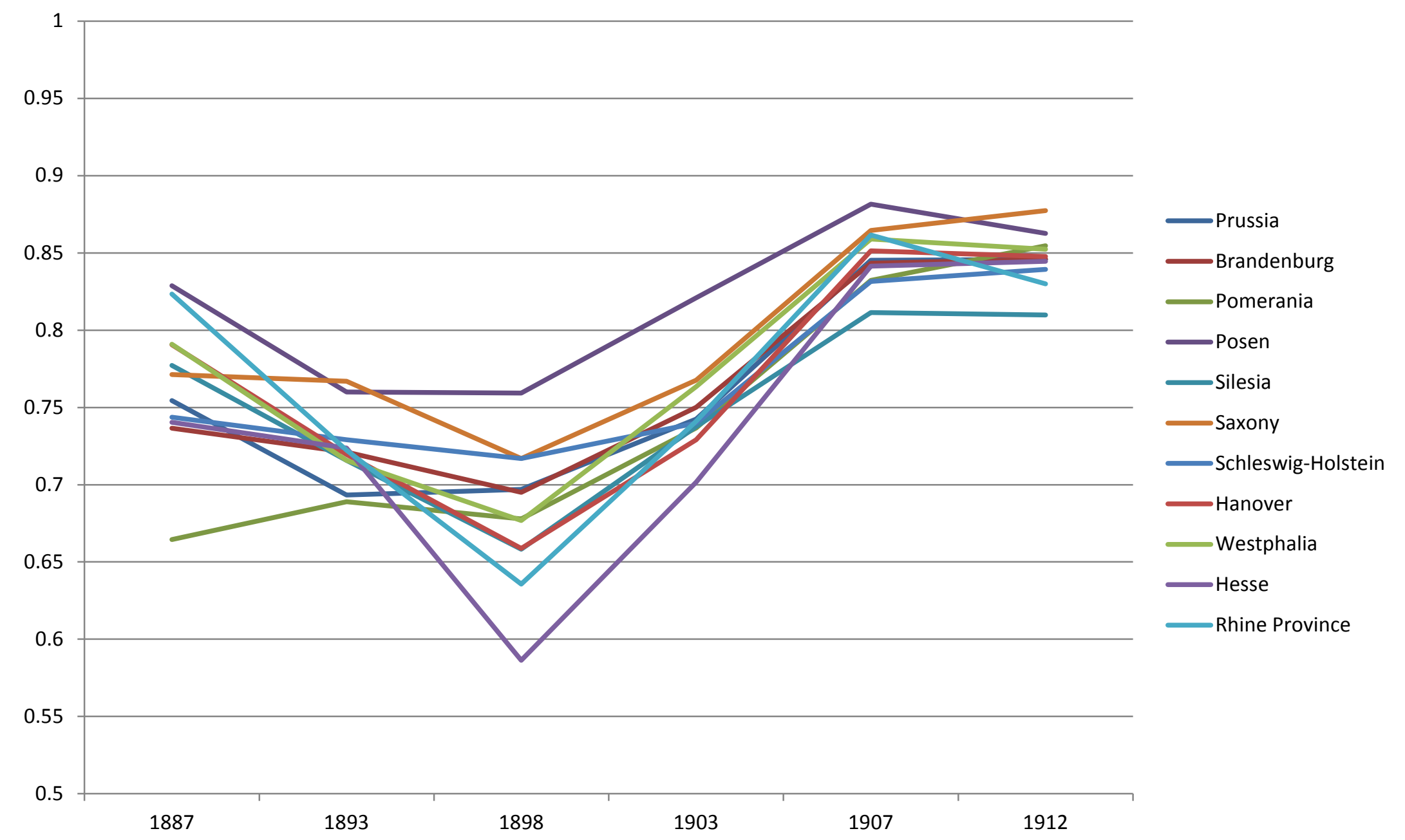

Note: Voter turnout is constructed as the number of votes divided by the electorate. As the province of Hohenzollern consists of only one constituency, we merge data on the provinces of Hohenzollern and Westphalia. See Appendix $3 \mathrm{~A}$ for data sources and details. 
Figure 5: Share of pro-nationalist votes by province, 1887-1912

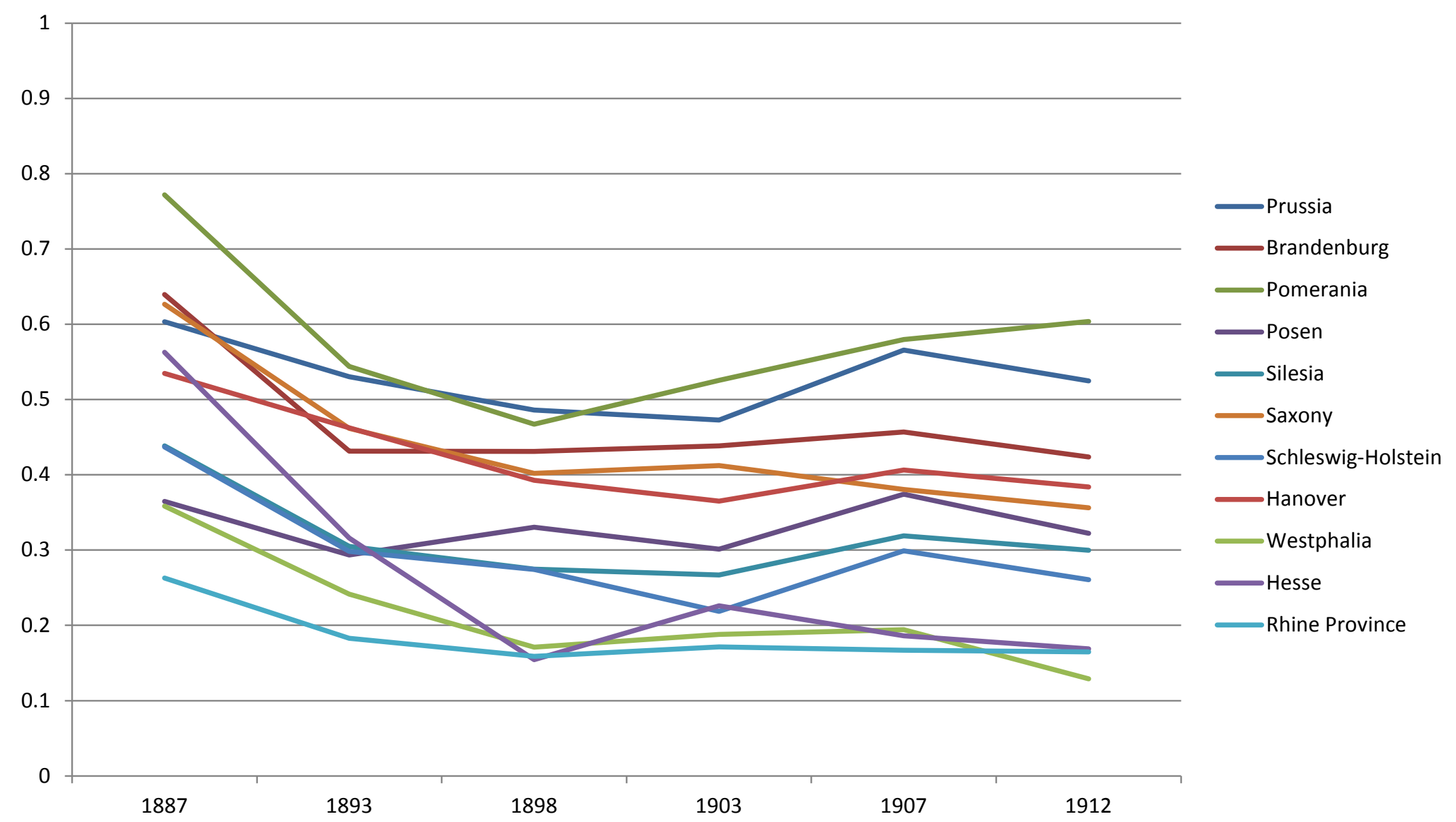

Note: The share of pro-nationalist votes is constructed by summing votes for the Free Conservative Party, the German Conservative Party, and the National Liberal Party and then dividing this sum by the total number of valid votes. As the province of Hohenzollern consists of only one constituency, we merge data on the provinces of Hohenzollern and Westphalia. See Appendix 3A for data sources and details. 
Voter turnout varies also over time and space, as can be seen in Figure 4. A drop in voter turnout is observed in all provinces for the elections of 1898. However, voter turnout recovered and exceeded 80 percent in all provinces of Prussia in the subsequent elections. The high voter turnout, despite the rather mediocre role of the Reichstag, is explained by historians as a manifestation of the duty to participate in elections (Partizipationspostulat). Put differently, the right to vote was in reality understood as an obligation to vote (Kühne, 1997).

Pro-nationalist parties see a sharp decline in support between the elections of 1887 and 1898, decreasing from about 50 percent of the vote share to about 30 percent on average. After 1898, the vote share for pro-nationalist parties levels off at about 35 percent. The fairly persistent high share of pro-nationalist delegates in the Reichstag shows that pro-nationalist parties continued to win constituencies even though the overall support for their parties decreased, a phenomenon explained by the majority voting system where the pro-nationalist candidates often managed to win the run-off ballots. As shown in Figure 5, the highest vote shares for the pro-nationalist parties are found in Pomerania and the province of Prussia, which were dominated by the landed elite. Very low support comes from the provinces of Posen, Westphalia, and the Rhineland. Predominantly Catholic Westphalia and the Rhine Province were strongholds of the Center Party. In Posen, home to a large Polish-speaking population, a majority of voters unsurprisingly supported the Polish party.

\section{$5 \quad$ Panel estimates}

The panel structure of the data allows estimating a model with constituency-fixed effects to examine the relationship between educational expenditures and voter turnout and the share of pronationalist votes, respectively. The fixed-effects model accounts for time-invariant unobserved characteristics of each constituency. For example, it could be the case that certain constituencies had systematically higher levels of social capital, leading to higher voter turnout. Alternatively, certain constituencies may have experienced historically particularly dominant, charismatic pronationalist politicians, leaving a legacy of voting pro-nationalist. These time-invariant characteristics are captured by the constituency-fixed effects.

Another possible concern is reversed causality. Constituencies with a higher pro-nationalist vote share might be rewarded by a higher share of state spending. ${ }^{17}$ We will partially address this issue by including lagged values of the share of central spending. Furthermore, time-variant unobserved variables might have an impact on central spending and electoral outcomes introducing

\footnotetext{
${ }^{17}$ See Curto-Grau et al. (2014) for political nepotism in the allocation of funding for roads infrastructure in nineteenth century Spain.
} 
an omitted variable bias. For example, other investments by the central state, such as in transport infrastructure or poor relief might influence electoral outcomes. If these investments are positively correlated with central investments in primary school, we might overestimate the relationship between the share of central spending on education and electoral outcomes. ${ }^{18}$ This potential bias has to be kept in mind when interpreting the results.

In the regression analysis we first look at the relationship between overall spending on education and our variables for electoral outcomes. In a second step we look at the composition of education spending including the share of central spending. The estimation equation for our main specification is the following:

$$
Y_{i t}=\beta_{1} c_{i t}+\beta_{2} s_{i t}+\beta_{3} X_{i t}+a_{i}+d_{t}+u_{i t}
$$

where $Y_{i t}$ denotes voter turnout and the vote share for pro-nationalist parties in constituency $i$ in year $t$, respectively. $c_{i t}$ denotes the share of central state expenditures out of total educational expenditures, while $s_{i t}$ denotes the log of total expenditures on education per student. $X$ denotes the vector of controls, which includes the urban share, the population density, the share of Protestants, the share of non-German-speaking students, landownership concentration and the share of the total population employed in manufacturing. We additionally include the dummy variable for whether a run-off ballot took place in the constituency in the estimations on voter turnout. As mentioned above, in the estimations on support for pro-nationalist parties, we additionally control for voter turnout and whether the delegate in the previous legislative period belonged to a pro-nationalist party. $a_{i}$ and $d_{t}$ denote constituency and year-fixed effects, respectively, whereas $u_{i t}$ denotes the error term. We expect a higher share of central state expenditures to increase both voter turnout and the share of votes for pro-nationalist parties because, on one hand, it relieved local authorities from funding primary schools, and on the other hand, it allowed for a more direct control of the central state on educational matters.

\subsection{Voter turnout}

Column 1 of Table 4 shows the unconditional correlation between the log of overall spending on education and voter turnout. The coefficient is small and insignificant. The relationship remains small and insignificant also when including our standard control variables in column 2 and 3. Once considering the composition of expenditures in column 4 by including the share of central

\footnotetext{
${ }_{18}$ Unfortunately there are no data available at the county level on central and local spending on other public goods.
} 
state expenditures, landownership concentration has a large and strong positive relationship with voter turnout whereas the share of people employed in manufacturing has a negative relationship.

We argue that in the context of Prussia, where the central state carefully controlled and monitored the educational content of primary education, it is the share of central spending that should affect the political participation and preferences of the population. Indeed, the estimates in columns 4-6 indicate that, for a given level of total expenditure on primary education, the share of central spending is positively related with voter turnout. This result holds when including our standard set of control variables as in columns 5 and 6 . In terms of magnitude, if we consider the full specification in column 6 , an increase of the share of central spending from zero to 100 percent is associated with an increase of voter turnout by 7 percentage points. Alternatively, an increase of the share of central spending by one standard deviation (0.16) is associated with an increase of voter turnout by about 1 percentage point.

\subsection{Pro-nationalist vote share}

In Table 5 we show the results of the regressions of the share of pro-nationalist votes on educational spending. In columns 1-3 we analyze the relationship between total spending on education and pro-nationalist political preferences. As one can see there is no significant relationship. However, the results in columns 4-8 support our claim that, for a given level of total spending on education, the share of central spending affected the political preferences of the population. This positive relationship is robust to the introduction of our rich set of control variables. In terms of magnitude, the coefficient indicates that increasing the share of central spending from zero to 100 percent is associated with an increase of the share of pro-nationalist votes between 20 and 30 percentage points. Alternatively, an increase of the share of central spending by one standard deviation is associated with an increase of political preferences for pro-nationalist parties between 3 and 5 percentage points.

The coefficients for the control variables reveal some interesting results. As expected we find that Protestants constituencies were strongly supportive of pro-nationalist parties. The coefficient for the share of non-German speaking students is negative although statistically insignificant. This is consistent with the notion that Polish-speaking areas were against nationalistic policies of the Prussian government. 
Table 4: Spending on education and voter turnout

\begin{tabular}{|c|c|c|c|c|c|c|}
\hline Dependent variable: Voter turnout & $(1)$ & $(2)$ & (3) & (4) & $(5)$ & (6) \\
\hline Central spending (share) & & & & $\begin{array}{c}0.094 * * * \\
(0.036)\end{array}$ & $\begin{array}{c}0.087^{* *} \\
(0.037)\end{array}$ & $\begin{array}{l}0.071^{*} \\
(0.040)\end{array}$ \\
\hline Log total spending per student & $\begin{array}{c}0.002 \\
(0.018)\end{array}$ & $\begin{array}{l}-0.000 \\
(0.019)\end{array}$ & $\begin{array}{c}0.001 \\
(0.019)\end{array}$ & $\begin{array}{c}0.009 \\
(0.018)\end{array}$ & $\begin{array}{c}0.007 \\
(0.019)\end{array}$ & $\begin{array}{c}0.008 \\
(0.019)\end{array}$ \\
\hline Urbanization rate & & $\begin{array}{l}-0.095 \\
(0.058)\end{array}$ & $\begin{array}{l}-0.082 \\
(0.060)\end{array}$ & & $\begin{array}{l}-0.064 \\
(0.060)\end{array}$ & $\begin{array}{l}-0.071 \\
(0.061)\end{array}$ \\
\hline Population density & & $\begin{array}{c}-0.044^{* *} \\
(0.020)\end{array}$ & $\begin{array}{l}-0.009 \\
(0.014)\end{array}$ & & $\begin{array}{l}-0.011 \\
(0.016)\end{array}$ & $\begin{array}{c}0.008 \\
(0.015)\end{array}$ \\
\hline Protestant (share) & & $\begin{array}{l}-0.052 \\
(0.171)\end{array}$ & $\begin{array}{c}0.052 \\
(0.180)\end{array}$ & & $\begin{array}{l}-0.009 \\
(0.183)\end{array}$ & $\begin{array}{c}0.086 \\
(0.181)\end{array}$ \\
\hline Non-German students (share) & & $\begin{array}{l}-0.138 \\
(0.103)\end{array}$ & $\begin{array}{l}-0.143 \\
(0.103)\end{array}$ & & $\begin{array}{l}-0.136 \\
(0.102)\end{array}$ & $\begin{array}{l}-0.143 \\
(0.101)\end{array}$ \\
\hline Landownership concentration & & & $\begin{array}{c}0.724 * * * \\
(0.165)\end{array}$ & & & $\begin{array}{c}0.718^{* * *} \\
(0.164)\end{array}$ \\
\hline Employed in manufacturing (share) & & & $\begin{array}{l}-0.090 \\
(0.059)\end{array}$ & & & $\begin{array}{l}-0.028 \\
(0.067)\end{array}$ \\
\hline Constituency FE & Yes & Yes & Yes & Yes & Yes & Yes \\
\hline Year FE & Yes & Yes & Yes & Yes & Yes & Yes \\
\hline Observations & 1194 & 1194 & 1194 & 1194 & 1194 & 1194 \\
\hline R-squared & 0.64 & 0.64 & 0.66 & 0.64 & 0.65 & 0.66 \\
\hline
\end{tabular}

$0.64 \quad 0.64$

0.66

0.64

0.65

0.66

Note: Panel estimates with constituency and year fixed effects. The dependent variable is the voter turnout computed as the number of votes divided by the electorate. Share central spending denotes the share of primary education spending contributed by the central state. Log total spending per student is computed as the logarithm of central plus local spending on public primary education per student. Urbanization rate is the share of people living in cities. Population density is the number of people (*100) per hectare. The variable for non-German students denotes the share of students who speak a language other than German at home. Landownership concentration is constructed as the number of farms larger than 100 hectares over the total number of farms and values for 1891, 1901, and 1911 are linearly interpolated. Employed in manufacturing denotes the share of people employed in manufacturing and values for 1891, 1901, and 1911 are interpolated. Robust standard errors reported in parentheses are clustered at the constituency level. ***, **, and * denote significance at $10 \%, 5 \%$, and $1 \%$, respectively. 
A large share of people employed in manufacturing is, as expected, negatively related to pronationalist political attitudes. We also find, perhaps surprisingly, that the share of large landowners is negatively related to the share of pro-nationalist votes. A strong concentration of large landownership implies a large share of small landholders and of landless people. These people likely had political preferences more aligned with the social democratic parties and that might explain the negative coefficient. ${ }^{19}$

In columns 7 and 8 we include, respectively, voter turnout and a variable which indicates whether the constituency had a pro-nationalist delegate in the previous legislature. We find that voter turnout is negatively related to pro-nationalist political attitudes. The results in column 8 suggest some "persistence" in the political attitudes of the constituency: a pro-nationalist delegate in the previous legislature is positively associated with the share of pro-nationalist votes. Important for our argument, the relationship between central spending and pro-nationalist political attitudes remains unaffected.

\subsection{Allocation of central spending}

So far our results are consistent with the interpretation that the share of central spending on education affected the political participation and the political attitudes of the population. Our data allow distinguishing the allocation of central and local spending for some categories. In particular, we can observe the amount of funding that went separately to teachers and to school buildings. ${ }^{20}$ Therefore we can further investigate whether different types of central expenses had a different impact on political outcomes.

A new school building, constructed with central funding, would have been clearly visible to voters and signaled the presence and interest of the state for the constituency. On the other hand, teacher salaries accounted for two-thirds of primary school expenditures and higher central state contributions for personnel hence meant major relief for local authorities. In fact, the central state funded 33.5 percent of teachers' expenditures, whereas it funded only 12.5 percent of building expenditures over the entire period of observation. Teachers paid with central state funds might have also contributed to instill pro-nationalist values in their pupils and their respective families. We therefore expect a higher share of central state spending for teachers as well as for buildings to be positively associated with voter turnout and pro-nationalist vote share.

\footnotetext{
${ }^{19}$ Indeed, if we use the share of votes for the social democratic party as dependent variable, the coefficient for the share of large landownership turns positive.

${ }^{20}$ Expenditures for teachers also include maintenance expenditures. For the years 1906 and 1911, central expenditures for teachers and maintenance are reported in one category (laufende Schulunterbaltungskosten) which is why we group these two categories into one for the whole period of observation.
} 
Table 5: Spending on education and pro-nationalist vote share

\begin{tabular}{|c|c|c|c|c|c|c|c|c|}
\hline Dependent variable: Pro-nationalist vote share & $(1)$ & $(2)$ & (3) & (4) & $(5)$ & (6) & $(7)$ & $(8)$ \\
\hline Central spending (share) & & & & $\begin{array}{c}0.272^{* * *} \\
(0.073)\end{array}$ & $\begin{array}{c}0.294 * * * \\
(0.073)\end{array}$ & $\begin{array}{c}0.212^{* *} \\
(0.083)\end{array}$ & $\begin{array}{c}0.221 * * * \\
(0.081)\end{array}$ & $\begin{array}{r}0.208^{* * *} \\
(0.078)\end{array}$ \\
\hline Log total spending per student & $\begin{array}{c}0.015 \\
(0.038)\end{array}$ & $\begin{array}{c}0.018 \\
(0.037)\end{array}$ & $\begin{array}{c}0.006 \\
(0.038)\end{array}$ & $\begin{array}{c}0.037 \\
(0.037)\end{array}$ & $\begin{array}{c}0.043 \\
(0.037)\end{array}$ & $\begin{array}{c}0.027 \\
(0.038)\end{array}$ & $\begin{array}{c}0.028 \\
(0.037)\end{array}$ & $\begin{array}{c}0.040 \\
(0.036)\end{array}$ \\
\hline Urbanization rate & & $\begin{array}{l}-0.033 \\
(0.148)\end{array}$ & $\begin{array}{c}0.083 \\
(0.145)\end{array}$ & & $\begin{array}{c}0.072 \\
(0.146)\end{array}$ & $\begin{array}{c}0.116 \\
(0.145)\end{array}$ & $\begin{array}{c}0.107 \\
(0.146)\end{array}$ & $\begin{array}{c}0.103 \\
(0.138)\end{array}$ \\
\hline Population density & & $\begin{array}{l}-0.109 \\
(0.075)\end{array}$ & $\begin{array}{l}-0.046 \\
(0.059)\end{array}$ & & $\begin{array}{c}0.005 \\
(0.061)\end{array}$ & $\begin{array}{c}0.006 \\
(0.060)\end{array}$ & $\begin{array}{c}0.007 \\
(0.061)\end{array}$ & $\begin{array}{l}-0.005 \\
(0.055)\end{array}$ \\
\hline Protestant (share) & & $\begin{array}{c}0.762^{* *} \\
(0.339)\end{array}$ & $\begin{array}{c}0.699 * * \\
(0.354)\end{array}$ & & $\begin{array}{c}0.907 * * * \\
(0.321)\end{array}$ & $\begin{array}{c}0.801^{* *} \\
(0.348)\end{array}$ & $\begin{array}{c}0.812^{* *} \\
(0.356)\end{array}$ & $\begin{array}{c}0.774 * * \\
(0.331)\end{array}$ \\
\hline Non-German students (share) & & $\begin{array}{l}-0.038 \\
(0.183)\end{array}$ & $\begin{array}{l}-0.017 \\
(0.179)\end{array}$ & & $\begin{array}{l}-0.032 \\
(0.172)\end{array}$ & $\begin{array}{l}-0.019 \\
(0.174)\end{array}$ & $\begin{array}{l}-0.037 \\
(0.178)\end{array}$ & $\begin{array}{l}-0.013 \\
(0.175)\end{array}$ \\
\hline Landownership concentration & & & $\begin{array}{c}-0.442^{*} \\
(0.232)\end{array}$ & & & $\begin{array}{c}-0.458^{* *} \\
(0.220)\end{array}$ & $\begin{array}{l}-0.365 \\
(0.230)\end{array}$ & $\begin{array}{l}-0.350 \\
(0.228)\end{array}$ \\
\hline Employed in manufacturing (share) & & & $\begin{array}{c}-0.474 * * * \\
(0.135)\end{array}$ & & & $\begin{array}{c}-0.290^{*} \\
(0.152)\end{array}$ & $\begin{array}{c}-0.293^{*} \\
(0.152)\end{array}$ & $\begin{array}{l}-0.243^{*} \\
(0.146)\end{array}$ \\
\hline Voter turnout & & & & & & & $\begin{array}{l}-0.129 \\
(0.085)\end{array}$ & $\begin{array}{l}-0.107 \\
(0.085)\end{array}$ \\
\hline Pro-nationalist delegate (dummy) & & & & & & & & $\begin{array}{r}0.071^{* * *} \\
(0.018)\end{array}$ \\
\hline Constituency FE & Yes & Yes & Yes & Yes & Yes & Yes & Yes & Yes \\
\hline Year FE & Yes & Yes & Yes & Yes & Yes & Yes & Yes & Yes \\
\hline Observations & 1194 & 1194 & 1194 & 1194 & 1194 & 1194 & 1194 & 1194 \\
\hline R-squared & 0.27 & 0.28 & 0.29 & 0.29 & 0.29 & 0.30 & 0.30 & 0.33 \\
\hline
\end{tabular}

Note: Panel estimates with constituency and year fixed effects. The dependent variable is the pro-nationalist vote share computed as the sum of votes for the Free Conservative Party, the German Conservative Party, and the National Liberal Party over the total number of valid votes. Share central spending denotes the share of primary education spending contributed by the central state. Log total spending per student is computed as the logarithm of central plus local spending on public primary education per student. Urbanization rate is the share of people living in cities. Population density is the number of people $(* 100)$ per hectare. The variable for non-German students denotes the share of students who speak a language other than German at home. Landownership concentration is constructed as the number of farms larger than 100 hectares over the total number of farms and values for 1891, 1901, and 1911 are linearly interpolated. Employed in manufacturing denotes the share of people employed in manufacturing and values for 1891, 1901, and 1911 are interpolated. Robust standard errors reported in parentheses are clustered at the constituency level. ***, **, and * denote significance at $10 \%, 5 \%$, and $1 \%$, respectively. 
We estimate equation (1) using the share of central spending for the respective category controlling for overall expenditures in the same category. The results are presented in Table 6. The associations between the shares of central spending in the different categories and the political outcomes are positive, though only significant for the pro-nationalist votes. In that case, the share of central spending on teachers seems to have a larger impact than spending on buildings (columns 3 and 4). ${ }^{21} \mathrm{~A}$ higher share of central spending for teachers means that more pro-nationalist teachers might have been selected. At the same time teachers were viewed as persons of respect (Respektsperson) in their communities, whose opinion and advice were considered by the local population when it came to voting decisions (Deppisch and Meisinger, 1992). This might have influenced voting toward the pro-nationalist parties.

Table 6: Allocation of central spending

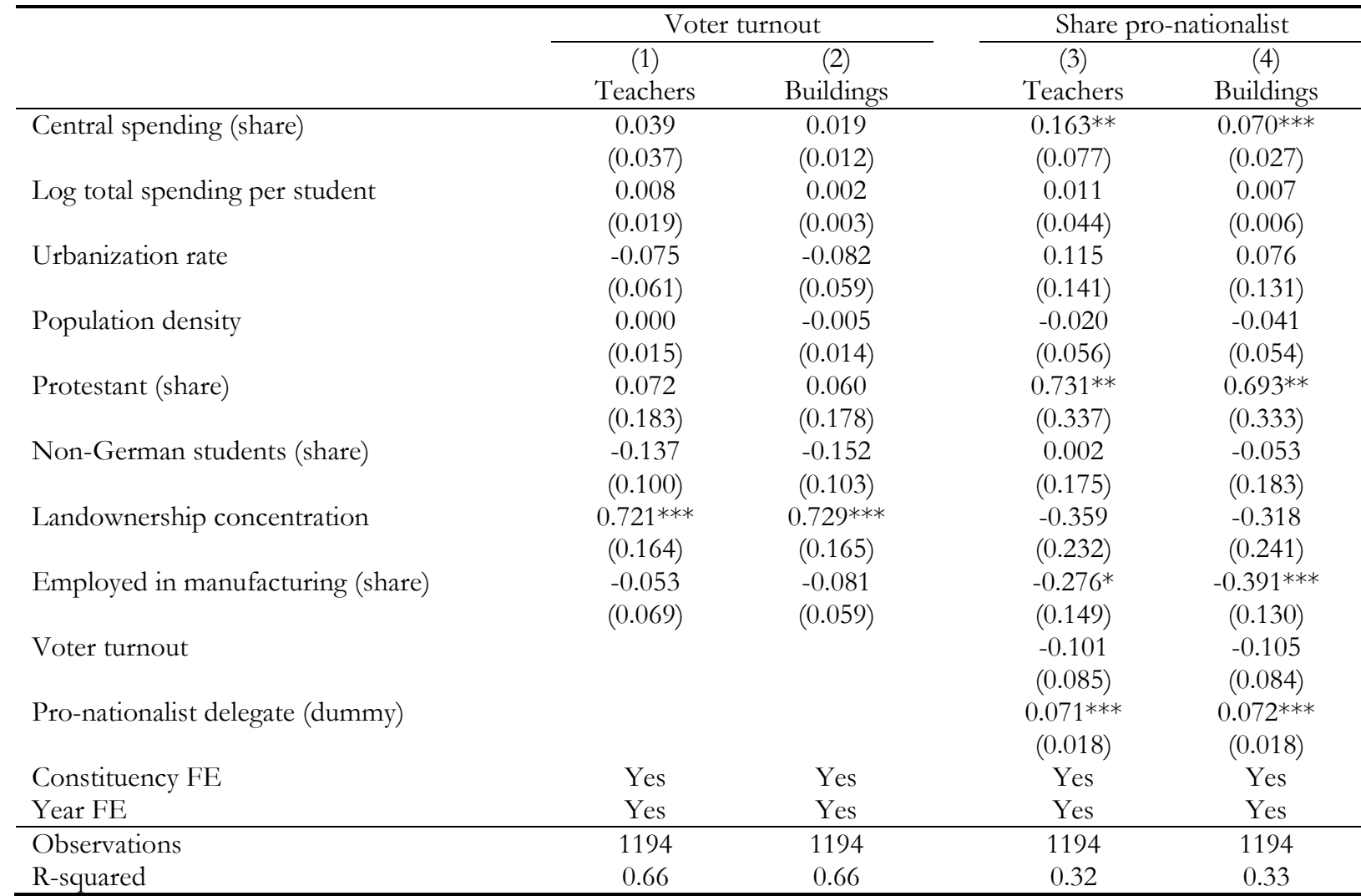

Note: Panel estimates with constituency and year fixed effects. In columns 1-2 the dependent variable is voter turnout computed as the number of votes divided by the electorate. In columns 3-4 the dependent variable is the pronationalist vote share computed as the sum of votes for the Free Conservative Party, the German Conservative Party, and the National Liberal Party over the total number of valid votes. The share of central spending and log total spending per student refer to teachers or buildings as indicated in the column headings. Urbanization rate is the share of people living in cities. Population density is the number of people $(* 100)$ per hectare. The variable for nonGerman students denotes the share of students who speak a language other than German at home. Landownership concentration is constructed as the number of farms larger than 100 ha over the total number of farms. Employed in manufacturing denotes the share of people employed in manufacturing and values for 1891, 1901, and 1911 are in-

${ }^{21}$ That the coefficients on the share of central spending for teachers and for buildings do not sum up to the coefficient on the share of central spending in Column 6 of Table 4 follows from the fact that the shares by category of spending are computed over the total by category and not over the total spending on primary education. 
terpolated. Voter turnout is the number of votes divided by the electorate. Pro-nationalist delegate is a dummy variable taking the value 1 if the delegate of the previous election year was a member of the Free Conservative Party, the German Conservative Party, or the National Liberal Party. Robust standard errors reported in parentheses are clustered at the constituency level. $* * *, * *$, and $*$ denote significance at $10 \%, 5 \%$, and $1 \%$, respectively.

\subsection{Subgroup analysis}

Did the composition of school expenditures align certain segments of the society with the Prussian ideal or did it simply strengthen the support of those who had already internalized this ideal? Prussian society at the turn of the century was polarized socially, religiously, and ethnolinguistically. While nation-building worked mainly through demarcation-against the Social Democrats, the Catholics, and the Poles-landlords in rural areas, the Protestant clergy, and local politicians managed to influence the views of the local population, an endeavor supported by the growing impact of the press (Kühne, 1997). Glück (1979) states that the Prussian Junkers, the Polish aristocracy, the Catholic Church, conservative local governments and administrations and the army were the main interest groups involved in school policy.

Gradstein and Justman (2005) argue that public education promotes assimilation of minorities. As the Prussian authorities understood school as an integration tool, we want to examine whether central state expenditures proved especially effective in regions with a high share of a particular minority group, on the one hand, or particular interest groups supportive of the Prussian state, on the other.

To examine this issue, we look at constituencies with a high share of non-German-speaking students, a high share of Catholics, and a high share of people employed in manufacturing, all of which were minorities that opposed the pro-nationalist ideals. Furthermore, we compute two measures for linguistic and religious polarization. ${ }^{22}$ We also look at highly urbanized constituencies, constituencies with high landownership concentration, constituencies with a pro-nationalist delegate, and swing constituencies. We examine how these subgroups reacted to a higher share of central state funding. We estimate the following equation:

$$
Y_{i t}=\beta_{1} c_{i t}+\beta_{2} s_{i t}+\beta_{3} g_{i t}+\beta_{4}(g * c)_{i t}+\beta_{5} X_{i t}+\alpha_{i}+c_{t}+u_{i t}
$$

where $g_{i t}$ indicates the subgroup and $(g * c)_{i t}$ indicates the interaction between the subgroup and the share of central funding in constituency $i$ in time $t$. The rest of the notation follows that

\footnotetext{
22 The polarization index measures how far the distribution of the groups is from a bipolar distribution, which represents the highest level of polarization. We use the polarization index proposed by Esteban and Ray (1994). See the appendix for the list of languages reported in each educational census used to construct the polarization index. The religious polarization index is based on five religious denominations as reported in the population census: Catholic, Protestant, other Christian, Jewish, and other religion.
} 
of equation (1). The results of the analysis are reported in Table 7 where each interaction is reported in a different column. In the upper panel A we report the results when using voter turnout as dependent variable; in panel B we use the share of pro-nationalist votes as dependent variable.

The results in Table 7 show important effect heterogeneity. The interaction term for the share of non-German students is negative and significant. This indicates that the positive impact of the share of central spending on voter turnout decreases with the share of non-German students. The total impact is in fact negative: Increasing the share of central state spending from 0 to 1 in a constituency that consists of exclusively non-German-speaking students decreases voter turnout by 3.3 percentage points. We find a similar result for Catholic constituencies: also in this case the impact of central spending on voter turnout decreases with the share of Catholics to the extent that the total effect is largely negative.

The interaction term for employment in manufacturing is insignificant, whereas we find significant negative interaction terms for constituencies linguistically (column 4) and religiously polarized (column 5). On the contrary, the share of central spending on education had an increasing impact on voter turnout in more urbanized constituencies and in constituencies with a pronationalist delegate in the previous legislature.

The estimates using the share of pro-nationalist votes as dependent variable (panel B) show that central spending on education had, in some cases, a positive impact on pro-nationalist vote in constituencies that had not such political preferences in absence of central spending. For instance, in constituencies with a large share of non-German speaking students or Catholic constituencies, the share of central spending on education increased political preferences for pronationalist parties (columns 1 and 2). On the contrary, an increase in central spending on education seems to have contributed to increase the anti-nationalistic preferences of constituencies with a large share of employment in manufacturing (column 3). Finally, we find a positive impact of central spending on education in constituencies polarized linguistically (column 4) and denominationally (column 5).

Therefore we find that the share of central spending on education contributed to increase the share of votes for pro-nationalist parties in constituencies originally not supportive of such parties and in constituencies socially polarized. Since in the analysis of pro-nationalist votes we control for voter turnout, a lower political participation cannot explain the positive impact of the share of central spending on pro-nationalist votes. 
Table 7: Subgroup analysis

\begin{tabular}{|c|c|c|c|c|c|c|c|c|}
\hline & $(1)$ & $(2)$ & (3) & $(4)$ & $(5)$ & (6) & $(7)$ & $(8)$ \\
\hline Subgroup & $\begin{array}{c}\text { Non-German } \\
\text { students }\end{array}$ & Catholics & $\begin{array}{l}\text { Employed in } \\
\text { manufacturing }\end{array}$ & $\begin{array}{c}\text { Linguistic } \\
\text { polarization }\end{array}$ & $\begin{array}{c}\text { Religious } \\
\text { polarization }\end{array}$ & Urbanization & $\begin{array}{l}\text { Landownership } \\
\text { concentration }\end{array}$ & $\begin{array}{c}\text { Pro-nationalist } \\
\text { delegate }\end{array}$ \\
\hline & \multicolumn{8}{|c|}{ Panel A: Dependent variable: Voter turnout } \\
\hline Central x Subgroup & $\begin{array}{c}-0.155^{* *} \\
(0.070)\end{array}$ & $\begin{array}{c}-0.323 * * * \\
(0.033)\end{array}$ & $\begin{array}{l}-0.147 \\
(0.192)\end{array}$ & $\begin{array}{c}-0.104^{* *} \\
(0.046)\end{array}$ & $\begin{array}{c}-0.118^{* *} \\
(0.047)\end{array}$ & $\begin{array}{l}0.311 * * \\
(0.133)\end{array}$ & $\begin{array}{c}0.676 \\
(0.689)\end{array}$ & $\begin{array}{c}0.160^{* * * *} \\
(0.030)\end{array}$ \\
\hline Central & $\begin{array}{c}0.122^{* * *} \\
(0.046)\end{array}$ & $\begin{array}{c}0.141 * * * \\
(0.038)\end{array}$ & $\begin{array}{l}0.089^{*} \\
(0.050)\end{array}$ & $\begin{array}{c}0.131^{* * * *} \\
(0.050)\end{array}$ & $\begin{array}{c}0.144 * * * \\
(0.049)\end{array}$ & $\begin{array}{c}0.003 \\
(0.050)\end{array}$ & $\begin{array}{c}0.048 \\
(0.044)\end{array}$ & $\begin{array}{l}-0.031 \\
(0.038)\end{array}$ \\
\hline Subgroup & $\begin{array}{l}-0.077 \\
(0.120)\end{array}$ & $\begin{array}{c}0.101 * * * \\
(0.017)\end{array}$ & $\begin{array}{c}0.001 \\
(0.077)\end{array}$ & $\begin{array}{c}0.066 \\
(0.062)\end{array}$ & $\begin{array}{c}0.242 * * * \\
(0.062) \\
\end{array}$ & $\begin{array}{l}-0.138^{*} \\
(0.070)\end{array}$ & $\begin{array}{c}0.437 \\
(0.307)\end{array}$ & $\begin{array}{c}-0.057 * * * \\
(0.011)\end{array}$ \\
\hline R-squared & 0.66 & 0.69 & 0.66 & 0.66 & 0.67 & 0.66 & 0.66 & 0.68 \\
\hline & \multicolumn{8}{|c|}{ Panel B: Dependent variable: Pro-nationalist vote share } \\
\hline Central x Subgroup & $\begin{array}{c}0.285^{* * *} \\
(0.095)\end{array}$ & $\begin{array}{c}0.271 * * * \\
(0.076)\end{array}$ & $\begin{array}{c}-0.805^{* *} \\
(0.371)\end{array}$ & $\begin{array}{c}0.172^{* *} \\
(0.083)\end{array}$ & $\begin{array}{c}0.273^{* * *} \\
(0.095)\end{array}$ & $\begin{array}{c}0.021 \\
(0.232)\end{array}$ & $\begin{array}{l}1.324 \\
(0.999)\end{array}$ & $\begin{array}{l}-0.078 \\
(0.056)\end{array}$ \\
\hline Central & $\begin{array}{c}0.114 \\
(0.090)\end{array}$ & $\begin{array}{c}0.115 \\
(0.079)\end{array}$ & $\begin{array}{c}0.308^{* * *} \\
(0.087)\end{array}$ & $\begin{array}{c}0.112 \\
(0.096)\end{array}$ & $\begin{array}{c}0.035 \\
(0.100)\end{array}$ & $\begin{array}{c}0.204 * * \\
(0.091)\end{array}$ & $\begin{array}{l}0.162^{*} \\
(0.090)\end{array}$ & $\begin{array}{c}0.257 * * * \\
(0.084)\end{array}$ \\
\hline Subgroup & $\begin{array}{l}-0.132 \\
(0.181) \\
\end{array}$ & $\begin{array}{c}-0.087 * * * \\
(0.031) \\
\end{array}$ & $\begin{array}{l}-0.083 \\
(0.146) \\
\end{array}$ & $\begin{array}{c}0.069 \\
(0.073) \\
\end{array}$ & $\begin{array}{c}0.057 \\
(0.181) \\
\end{array}$ & $\begin{array}{c}0.098 \\
(0.143) \\
\end{array}$ & $\begin{array}{l}-0.898^{*} \\
(0.484) \\
\end{array}$ & $\begin{array}{c}0.094 * * * \\
(0.025) \\
\end{array}$ \\
\hline R-squared & 0.33 & 0.33 & 0.33 & 0.33 & 0.33 & 0.33 & 0.33 & 0.33 \\
\hline Constituency FE & Yes & Yes & Yes & Yes & Yes & Yes & Yes & Yes \\
\hline Year FE & Yes & Yes & Yes & Yes & Yes & Yes & Yes & Yes \\
\hline Controls & Yes & Yes & Yes & $\mathrm{Ye}$ & Yes & Yes & Yes & Yes \\
\hline Observations & 1194 & 1194 & 1194 & 1194 & 1194 & 1194 & 1194 & 1194 \\
\hline Mean of Subgroup (\%) & 13.1 & 32.3 & 14.6 & 20.8 & 44.6 & 34.5 & 2.3 & 44.2 \\
\hline
\end{tabular}

Note: Panel estimates with constituency and year fixed effects. For the definition of the variables, see notes to previous tables. Linguistic polarization is measured through the polarization index as in Esteban and Ray (1994). For the linguistic groups included, see Appendix 3A. Religious polarization is similarly measured through the polarization index and is based on five religious groups as reported in the population censuses: Protestants, Catholics, other Christians, Jews, and other religion. Controls include the urbanization rate, population density $(* 100)$, share of Protestant, non-German students, landownership concentration, employed in manufacturing. Estimations in Panel B additionally include voter turnout and a dummy variable whether the delegate elected in the previous election was pro-nationalist. Robust standard errors reported in parentheses are clustered at the constituency level. $* * *, * *$, and $*$ denote significance at $10 \%, 5 \%$, and $1 \%$, respectively. 


\subsection{Lagged central spending}

To this point, we have looked at the "contemporaneous" association between spending on education and electoral outcomes, with a one or two-year lag between observed spending and electoral outcomes. As described above, school was used as a way of embedding Prussian values in students. The Royal Decree of Wilhelm II in 1889 declared the school as an instrument to fight social democracy and foster Prussian virtues. Do we find any evidence that indoctrination through schooling worked? Do we see higher voter turnout and higher vote share for pronationalist parties in constituencies that experienced higher central state spending when the electorate was still at school?

Men were eligible to vote at age 25. Thus, the youngest students of a cohort (being between 6 and 14 years old) entered the electorate 19 years later, the oldest ones 11 years later. Therefore we can observe part of a student cohort in the electorate after 15 years, that is, with a lag of 3 periods as our data are measured in five-year intervals. ${ }^{23}$

Students in 1886 vote in the elections of 1903 for the first time and students of 1891 and 1896 are first-time voters in the elections of 1907 and 1912, respectively. ${ }^{24}$ The variable central spending lagged 3 periods is therefore especially interesting because it captures central spending on primary education for voters who were in primary school at that time. In order to shed more light on the possible mechanism, we distinguish also between lagged spending on buildings and teachers. Since we lose the first three election years because of the inclusion of 3 lags, the number of observation is now 597.

The results of the estimates with lagged central spending are presented in Table 8. In column 1 and 5 we report the baseline fixed-effect model for the reduced sample. The relationship between central spending and voter turnout is not significant, whereas the relationship between central spending and pro-nationalist political preferences is positive and significant. For the case of voter turnout the estimates in column 2 indicate that an increase in the share of central spending has no contemporaneous impact on voter turnout. Yet the variables for the share of central spending lagged 1 and 2 periods have a negative impact on voter turnout (column 2). Estimates in column 3 and 4 suggest that this is related to central spending on teachers. This result is difficult to rationalize. However, it is consistent with the result by subgroup in the previous section where

\footnotetext{
${ }^{23}$ In this case we are assuming that primary school students who studied in a given constituency voted in the same constituency 15 years later. Given that the level of observation is a constituency, comprising on average between two and three counties, only long distance migration might cause biases. Data on long distance migration is available for the years 1901 and 1906. Including the share of people born outside of their residing province as a control variable for these two waves does not alter the results.

${ }^{24}$ According to a rough estimate dividing the student cohort by the electorate 15 years later, one student cohort could make up about one-third of the electorate once all students of the respective cohort achieved legal voting age.
} 
we have shown that, for certain groups, an increase in the share of central spending was related to a decrease in voter turnout. Here we find that an increase in the share of central spending in the previous 10 or 15 years had a persistent negative impact on political participation.

The results on the share of pro-nationalist votes are instead consistent with the "indoctrination hypothesis": pro-nationalist political attitudes are positively related to the contemporary share of central spending and to the share of central spending of 15 years earlier ${ }^{25}$ (column 6). This last result is consistent with the notion that voters might have been influenced during their formative years in primary school. This interpretation is further corroborated by the result that it is the share of central spending on teachers which has an effect on political outcomes 15 years later (column 7). Instead, the share of central spending on buildings has only a contemporaneous impact (column 8).

\section{Conclusion}

In this paper we investigate the effect of central spending on primary education on voter turnout and pro-nationalist political preferences. According to the historical narrative, the Prussian Kingdom used the educational system to form loyal subjects (Untertanenfabrik) stressing values such as voting, paying taxes, military service, school attendance, and respect for the authority. We argue that changes in central spending capture variation in the state control over schools and teachers which, in turn, influenced political outcomes.

Combining data on elections for the German federal parliament from 1887 to 1912 with data on local and central spending on education from 1886 to 1911 we estimate panel models with constituency and time-fixed effects which allow accounting for time-invariant characteristics and time-varying common shocks.

We find that, for a given level of total spending on education, an increase in the share of central spending is positively associated with voter turnout and with the share of pro-nationalist votes. Analysis of effect heterogeneity suggests that an increase in the share of central spending increased pro-nationalist political preferences in constituencies initially adverse to nationalistic values, for instance in constituencies with a large share of non-German speaking people or a large share of Catholics. The same result was obtained in constituencies strongly polarized linguistically or religiously.

Finally we have analyzed the persistence of these effects using a model with lagged independent variables, distinguishing between central spending on buildings and on teachers. Consistent

\footnotetext{
${ }^{25}$ The coefficients of the contemporaneous effect and the 15 years-time lag are only slightly below the conventional significance level.
} 
with the hypothesis that state-funded teachers might have indoctrinated their students, we find that the share of central spending on teachers has an impact on the share of pro-nationalist votes 15 years later, namely when the students become part of the electorate.

Overall, our results provide evidence on the role played by the central state and the instrumental role of the education system in shaping political participation and political preferences. 
Table 8: Lagged central spending

\begin{tabular}{|c|c|c|c|c|c|c|c|c|}
\hline \multirow[t]{2}{*}{ Dependent variable: } & \multicolumn{4}{|c|}{ Voter turnout } & \multicolumn{4}{|c|}{ Share pro-nationalist votes } \\
\hline & $\begin{array}{l}\text { Total } \\
(1)\end{array}$ & $\begin{array}{l}\text { Total } \\
(2)\end{array}$ & $\begin{array}{c}\text { Teachers } \\
\text { (3) }\end{array}$ & $\begin{array}{c}\text { Buildings } \\
\text { (4) }\end{array}$ & $\begin{array}{l}\text { Total } \\
(5)\end{array}$ & $\begin{array}{c}\text { Total } \\
(6)\end{array}$ & $\begin{array}{c}\text { Teachers } \\
(7)\end{array}$ & $\begin{array}{c}\text { Buildings } \\
(8)\end{array}$ \\
\hline \multirow[t]{2}{*}{ Central spending (share) } & 0.015 & 0.023 & 0.030 & -0.006 & 0.217 & 0.238 & 0.006 & $0.098^{* *}$ \\
\hline & $(0.068)$ & $(0.065)$ & $(0.048)$ & $(0.019)$ & $(0.152)$ & $(0.151)$ & $(0.130)$ & $(0.046)$ \\
\hline \multirow[t]{2}{*}{ Lag1 } & & $-0.135^{*}$ & -0.144 & -0.026 & & 0.082 & 0.033 & 0.076 \\
\hline & & $(0.079)$ & $(0.110)$ & $(0.021)$ & & $(0.188)$ & $(0.252)$ & $(0.056)$ \\
\hline \multirow[t]{2}{*}{ Lag2 } & & $-0.185^{* *}$ & $-0.247 * * *$ & -0.011 & & 0.130 & 0.156 & 0.102 \\
\hline & & $(0.083)$ & $(0.088)$ & $(0.029)$ & & $(0.216)$ & $(0.230)$ & $(0.071)$ \\
\hline \multirow[t]{2}{*}{ Lag3 } & & 0.051 & 0.083 & 0.013 & & 0.302 & $0.451 * *$ & -0.024 \\
\hline & & $(0.061)$ & $(0.082)$ & $(0.044)$ & & $(0.199)$ & $(0.201)$ & $(0.110)$ \\
\hline Constituency FE & Yes & Yes & Yes & Yes & Yes & Yes & Yes & Yes \\
\hline Year FE & Yes & Yes & Yes & Yes & Yes & Yes & Yes & Yes \\
\hline Controls & Yes & Yes & Yes & Yes & Yes & Yes & Yes & Yes \\
\hline Observations & 597 & 597 & 597 & 597 & 597 & 597 & 597 & 597 \\
\hline $\mathrm{R}$-squared & 0.70 & 0.71 & 0.72 & 0.71 & 0.07 & 0.10 & 0.10 & 0.09 \\
\hline
\end{tabular}

Note: Panel estimates with constituency and year fixed effects. In columns 1-4 the dependent variable is voter turnout computed as the number of votes divided by the electorate. In columns 5-8 the dependent variable is the pro-nationalist vote share computed as the sum of votes for the Free Conservative Party, the German Conservative Party, and the National Liberal Party over the total number of valid votes. Controls are: log of total spending on education per student, urbanization rate, population density $(* 100)$, share of Protestant, non-German students, landownership concentration, share employed in manufacturing. Log of total spending on education is also lagged. Specifications in columns $5-8$ include also voter turnout and a dummy for pro-nationalist delegate in the previous legislature as control variable. In columns 3 and 7 we consider the share of central spending on buildings. In column 4 and 8 we consider the share of central spending on teachers. Robust standard errors reported in parentheses are clustered at the constituency level. ***, $* *$, and $*$ denote significance at $10 \%, 5 \%$, and $1 \%$, respectively. 


\section{References}

Aidt, T.S., Dutta, Jayasri, Loukoianova, Elena, 2006. Democracy comes to Europe: franchise extension and fiscal outcomes 1830-1938. European Economic Review 50, 249-283.

Anderson, Eugene N, 1970. The Prussian Volksschule in the Nineteenth Century. In Entstehung Und Wandel Der Modernen Gesellschaft. Festschrift Für Hans Rosenberg Zum 65. Geburststag, edited by Gerhard A. Ritter, 261-79. Berlin: Walter de Gruyter.

Becker, Sascha, Francesco Cinnirella, Erik Hornung, and Ludger Woessmann, 2014. iPEHD - The ifo Prussian Economic History Database. Historical Methods: A Journal of Quantitative and Interdisciplinary History 47 (2), 57-66.

Calvo, Ernesto, and Maria Victoria Murillo, 2004. Who Delivers? Partisan Clients in the Argentine Electoral Market. American Journal of Political Science 48 (4), 742-57.

Cantoni, Davide, Yuyu Chen, David Y. Yang, Noam Yuchtman, and Y. Jane Zhang, 2015. Curriculum and Ideology. Journal of Political Economy, forthcoming.

Chaudhary, Latika, Aldo Musacchio, Steven Nafziger, and Se Yan, 2012. Big BRICs, weak foundations: The beginning of public elementary education in Brazil, Russia, India, and China. Exploration in Economic History 49, 221-240.

Cinnirella, Francesco, and Erik Hornung, 2016. Landownership Concentration and the Expansion of Education. Journal of Development Economics 121, 135-52.

Cinnirella, Francesco, and Ruth Schueler, 2016. The Cost of Decentralization: Linguistic Polarization and the Provision of Education. CESifo Working Paper 5894.

Clark, Christopher, 2007. Iron Kingdom. The Rise and Fall of Prussia, 1600-1947. London: Penguin Books.

Croke, Kevin, Guy Goossman, Horacio A. Larreguy, and John Marshall, 2015. Deliberate Disengagement: How Education Decreases Political Participation in Electoral Authoritarian Regimes. American Political Science Review, forthcoming.

Curto-Grau, Marta, Alfonso Herranz-Loncán, and Albert Solé-Ollé, 2014. Pork-Barrel Politics in Semi-Democracies: The Spanish "Parliamentary Roads" 1880-1914. Journal of Economic History 72 (3), 771-796.

Dee, Thomas S., 2004. Are There Civic Returns to Education?. Journal of Public Economics 88 (9-10), 1697-1720. 
Deppisch, Herbert, and Walter Meisinger, 1992. Vom Stand Zum Amt. Der Materielle Und Soziale Emanzipationsprozeß Der Elementarlehrer in Preußen. Wiesbaden: Deutscher Universitätsverlag.

Drazen, Allan, and Marcela Eslava, 2010. Electoral Manipulation via Voter-Friendly Spending: Theory and Evidence. Journal of Development Economics 92 (1), 39-52.

Engerman, Stanley L., Elisa Mariscal, Kenneth L. Sokoloff. 2009. The evolution of schooling in the Americas, 1800-1925. In: Eltis, David, Lewis, Frank D., Sokoloff, Kenneth L. (Eds.), Human Capital and Institutions: A Long Run View. Cambridge University Press, Cambridge, England, 93-142.

Engstrom, Erik J., and Georg Vanberg, 2010. Assessing the Allocation of Pork: Evidence From Congressional Earmarks. American Politics Research 38 (6), 959-85.

Gallego, Francisco A., 2010. Historical origins of schooling: the role of democracy and political decentralization. The Review of Economics and Statistics 92 (2), 228-243.

Galloway, Patrick R., 2007. Galloway Prussia Database 1861 to 1914, www.patrickgalloway.com

Glück, Helmut. 1979. Die Preußisch-Polnische Sprachenpolitik: Eine Studie Zur Theorie Und Methodologie Der Forschung Über Sprachenpolitik, Sprachbewußtsein Und Sozialgeschichte Am Beispiel Der Preußisch-Deutschen Politik. Gegenüber Der Polnischen Minderheit Vor 1914. Hamburg: Buske.

Go, Sun, and Peter H. Lindert, 2010. The Uneven Rise of Public Schools to 1850. Journal of Economic History 70(1), 1-26.

Gradstein, Mark, and Moshe Justman, 2005. The Melting Pot and School Choice. Journal of Public Economics 89 (5-6), 871-96.

Hagen, William W. 2002. Ordinary Prussians: Brandenburg Junkers and Villagers, 1500-1840. Cambridge, MA: Cambridge University Press.

Hoppe, Albrecht, and Rudolf Stöber, 2006. DFG-Projekt Digitalisierung Der Amtspresse Preußens in Der Zweiten Hälfte Des 19. Jahrhunderts Und Erstellung Eines Sachkommentars. Jahrbuch Für Kommunikationsgeschichte 8, 220-46.

James, Estelle, 1993. Why Do Different Countries Choose a Different Public-Private Mix of Educational Services?. Journal of Human Resources 28 (3), 571-92.

Jesse, Eckhard, 2013. Das Parteiensystem Des Kaiserreichs Und Der Weimarer Republik. In Handbuch Parteienforschung, 685-710. Wiesbaden: Springer. 
Kaiserliches Statistisches Reichsamt, 1872. Statistik Des Deutschen Reichs. Berlin: Kaiserliches Statistisches Amt.

Kennedy, Katharine D., 1997. A Nation's Readers: Cultural Integration and the Schoolbook Canon in Wilhelmine Germany. International Journal of the History of Education 33 (1), 459-80.

Klee, H., 1888. Steuerentlastungen. Neueste Mittheilungen, September 4.

Kochendörfer, Jürgen, 1997. Geschichte Und Geschehen, Band 3. Stuttgart/Berlin/Köln: Ernst Klett Verlag.

Koenig, Christoph, 2015. Loose Cannons - War Veterans and the Erosion of Democracy in Weimar Germany. Warwick Economics Research Paper Series 1079.

Königliches Statistisches Bureau in Berlin. Preussische Statistik, Vol. 1-305. Berlin: Verlag des Königlichen Statistischen Bureaus.

Kremer, Michael, and Andrei Sarychev, 2000. Why Do Governments Operate Schools?, mimeo.

Kuhlemann, Frank-Michael, 1991. "Schulen, Hochschulen, Lehrer." In Handbuch Der Deutschen Bildungsgeschichte, Band 4, 1870 - 1918: Von Der Reichsgründung Bis Zum Ende Des Ersten Weltkriegs, edited by Christa Berg, 179-370. München: Beck.

Kühne, Thomas, 1997. "Entwicklungstendenzen Der Preußischen Wahlkultur Im Kaiserreich." In Wablen Und Wablkämpfe in Deutschland. Von Den Anfängen Im 19. Jabrbundert Bis Zur Bundesrepublik., 131-67. Düsseldorf: Droste.

Kwon, Hyeok Yong, 2005. Targeting Public Spending in a New Democracy: Evidence from South Korea. British Journal of Political Science 35 (2), 321-41.

Lamberti, Marjorie, 1989. State, Society and the Elementary School in Imperial Germany. New York/Oxford: Oxford University Press.

Larcinese, Valentino, James M. Snyder, and Cecilia Testa, 2015. Testing Models of Distributive Politics Using Exit Polls to Measure Voters' Preferences and Partisanship. British Journal of Political Science 43 (4), 845-75.

Lazarus, Jeffrey, and Shauna Reilly, 2010. The Electoral Benefits of Distributive Spending. Political Research Quarterly 63 (2), 343-55.

Lehmann, Sibylle, 2010. The German Elections in the 1870s: Why Germany Turned from Liberalism to Protectionism. Journal of Economic History 70 (1), 146-178.

Leigh, Andrew, 2008. Bringing Home the Bacon: An Empirical Analysis of the Extent and 
Effects of Pork-Barreling in Australian Politics. Public Choice 137, 279-99.

Lepsius, Rainer M., 1993. "Parteiensystem Und Sozialstruktur. Zum Problem Der Demokratisierung Der Deutschen Gesellschaft." In Demokratie in Deutschland, edited by Rainer M. Lepsius, 25-50. Göttingen: Vandenhoeck \& Rupprecht.

Lindert, Peter H. 2004. Growing Public: Social Spending and Economic Growth since the Eighteenth Century, 2, Cambridge University Press, New York, NY.

Lott, John R., 1990. An Explanation for Public Provision of Schooling: The Importance of Indoctrination. Journal of Law and Economics 33 (1), 199-231.

Lott, John R., 1999. Public Schooling, Indoctrination, and Totalitarianism. Journal of Political Economy 107 (S6), 127-57.

Manacorda, Marco, Miguel Edward, and Andrea Vigorito, 2011. Government Transfers and Political Support. American Economic Journal: Applied Economics 3 (July), 1-28.

Moderow, Hans-Martin. 2007. "Das Kirchliche Stiftungsvermögen Der Evangelischen Volksschulen Und Sein Schicksal Bis in Das 20. Jahrhundert. Untersuchungen Zu Einem Grundlegenden Problem Der Volksschulfinanzierung Am Übergang Zur Moderne - Sachsen, Brandenburg Und Württemberg Im Vergl.” In Bildungsmäzenatentum. Privates Handeln - Bürgersinn - Kulturelle Kompeten₹ Seit Der Frühen Neuæeit, edited by Jonas Flöter and Christian Ritzi, 207-32. Köln: Böhlau Verlag.

Pritchett, Lant, and Martina Viarengo, 2013. The State, Socialisation, and Private Schooling: When Will Governments Support Alternative Producers?. Journal of Development Studies 51 (7), 784-807.

Reynolds, C. Lockwood, 2014. State Politics, Tuition, and the Dynamics of a Political Budget Cycle. Empirical Economics 46 (4), 1241-70.

Samuels, David J., 2002. Pork Barreling Is Not Credit Claiming or Advertising: Campaign Finance and the Sources of the Personal Vote in Brazil. Journal of Politics 64 (3), 84563.

Schueler, Ruth, 2016. Centralized Monitoring, Resistance, and Reform Outcomes: Evidence from School Inspections in Prussia, mimeo.

Sperber, Jonathan, 1997. The Kaiser's Voters. Electors and Elections in Imperial Germany. Cambridge, UK: Cambridge University Press.

Stratmann, Thomas, 2013. The Effects of Earmarks on the Likelihood of Reelection. European Journal of Political Economy 32, 341-55. 
Treisman, Daniel, 1996. The Politics of Intergovernmental Transfers in Post-Soviet Russia. British Journal of Political Science 26 (3), 299-335.

Ullmann, Hans-Peter. 1980. Das Deutsche Kaiserreich, 1871-1918. Frankfurt am Main: Suhrkamp.

Unruh, Georg-Christoph von. 1992. "Provinz (Großherzogtum) Posen." In Verwaltungsgeschichte Ostdeutschlands 1815-1945. Organisation - Aufgaben - Leistungen Der Verwaltung, edited by Gerd Heinrich, Friedrich-Wilhelm Henning, and Kurt G.A. Jeserich, 366-474. Stuttgart/Berlin/Köln: Verlag W. Kohlhammer.

Voigtländer, Nico and Hans-Joachim Voth, 2015. Nazi indoctrination and anti-Semitic beliefs in Germany. Proceedings of the National Academy of Sciences 112 (26), 7931-7936.

Voigtländer, Nico and Hans-Joachim Voth, 2014. Highway to Hitler. NBER Working Paper 20150.

Zippelius, Reinhold. 2006. Kleine Deutsche Verfassungsgeschichte: Vom Frühen Mittelalter Bis Zur Gegenwart. München: Beck. 


\section{Appendix - Data sources}

Table A1: $1886 / 1887$ variables

\begin{tabular}{|c|c|}
\hline Voter turnout & $\begin{array}{l}\text { Number of votes divided by the electorate in } 1887 \text { (Kaiserliches Statistisches } \\
\text { Reichsamt, 1872-1918). }\end{array}$ \\
\hline $\begin{array}{l}\text { Pro-nationalist vote } \\
\text { (share) }\end{array}$ & $\begin{array}{l}\text { Sum of votes for the Free Conservative Party, the German Conservative } \\
\text { Party, and the National Liberal Party divided by the total number of valid } \\
\text { votes in } 1887 \text { (Kaiserliches Statistisches Reichsamt, 1872-1918). }\end{array}$ \\
\hline $\begin{array}{l}\text { Total spending per stu- } \\
\text { dent }\end{array}$ & $\begin{array}{l}\text { Total expenditures for public primary education per student of mandatory } \\
\text { school age, } 6-14 \text {, in } 1886 .\end{array}$ \\
\hline Central spending (share) & $\begin{array}{l}\text { Share of total expenditures for public primary education contributed by state } \\
\text { grants or funds in } 1886 .\end{array}$ \\
\hline Urbanization rate & $\begin{array}{l}\text { Share of total population living in cities that held city rights in } 1885 \text { (Kö- } \\
\text { nigliches Statistisches Bureau in Berlin, 1861-1934, vol. 89). }\end{array}$ \\
\hline Population density & $\begin{array}{l}\text { Number of people per hectare in } 1885 \text { (Königliches Statistisches Bureau in } \\
\text { Berlin, 1861-1934, vol. 96). }\end{array}$ \\
\hline Protestant (share) & $\begin{array}{l}\text { Share of Protestants per total population in } 1885 \text { (Königliches Statistisches } \\
\text { Bureau in Berlin, 1861-1934, vol. 96). }\end{array}$ \\
\hline $\begin{array}{l}\text { Non-German students } \\
\text { (share) }\end{array}$ & $\begin{array}{l}\text { Share of non-German-speaking students per total students of mandatory } \\
\text { school age, } 6-14 \text {, in } 1886 .\end{array}$ \\
\hline Linguistic polarization & $\begin{array}{l}\text { Linguistic polarization is measured through the polarization index as de- } \\
\text { scribed in Equation (4.1) and is based on the linguistic groups reported in the } \\
\text { education census in 1886: German, Polish, Lithuanian, Wendish, Slavic, Dan- } \\
\text { ish, and "other" language. }\end{array}$ \\
\hline $\begin{array}{l}\text { Landownership concen- } \\
\text { tration }\end{array}$ & $\begin{array}{l}\text { Share of farms larger than } 100 \text { ha arable land in } 1882 \text { (Königliches Statis- } \\
\text { tisches Bureau in Berlin, 1861-1934, vol. 76c). }\end{array}$ \\
\hline $\begin{array}{l}\text { Employed in manufac- } \\
\text { turing (share) }\end{array}$ & $\begin{array}{l}\text { Share of people employed in manufacturing (sector B) over total population } \\
\text { in } 1882 \text { (Königliches Statistisches Bureau in Berlin, 1861-1934, vol. 76b). }\end{array}$ \\
\hline $\begin{array}{l}\text { Swing constituencies } \\
\text { (dummy) }\end{array}$ & $\begin{array}{l}\text { Variable takes value } 1 \text { if no party reached a share above } 50 \text { percent in the } \\
\text { first round of elections, } 0 \text { otherwise, in } 1887 \text { (Kaiserliches Statistisches } \\
\text { Reichsamt, 1872-1918). }\end{array}$ \\
\hline $\begin{array}{l}\text { Pro-nationalist delegate } \\
\text { (dummy) }\end{array}$ & $\begin{array}{l}\text { Variable takes value } 1 \text { if delegate belonged to the Free Conservative Party, } \\
\text { the German Conservative Party, or the National Liberal Party in Reichstag of } \\
\text { 1884, } 0 \text { otherwise (Kaiserliches Statistisches Reichsamt, 1872-1918). }\end{array}$ \\
\hline
\end{tabular}

Note: Unless otherwise specified, the data are from the Königliches Statistisches Bureau in Berlin (18611934, vol. 101). 
Table A2: 1891/1893 variables

\begin{tabular}{|c|c|}
\hline Voter turnout & $\begin{array}{l}\text { Number of votes divided by the electorate in } 1893 \text { (Kaiserliches Statistisches } \\
\text { Reichsamt, 1872-1918). }\end{array}$ \\
\hline $\begin{array}{l}\text { Pro-nationalist vote } \\
\text { (share) }\end{array}$ & $\begin{array}{l}\text { Sum of votes for the Free Conservative Party, the German Conservative } \\
\text { Party, and the National Liberal Party divided by the total number of valid } \\
\text { votes in } 1893 \text { (Kaiserliches Statistisches Reichsamt, 1872-1918). }\end{array}$ \\
\hline $\begin{array}{l}\text { Total spending per stu- } \\
\text { dent }\end{array}$ & $\begin{array}{l}\text { Total expenditures for public primary education per student of mandatory } \\
\text { school age, } 6-14 \text {, in } 1891 .\end{array}$ \\
\hline Central spending (share) & $\begin{array}{l}\text { Share of total expenditures for public primary education contributed by state } \\
\text { grants or funds in } 1891 .\end{array}$ \\
\hline Urbanization rate & $\begin{array}{l}\text { Share of total population living in cities that held city rights in } 1890 \text { (Kö- } \\
\text { nigliches Statistisches Bureau in Berlin, 1861-1934, vol. 117). }\end{array}$ \\
\hline Population density & $\begin{array}{l}\text { Number of people per hectare in } 1890 \text { (Königliches Statistisches Bureau in } \\
\text { Berlin, 1861-1934, vol. 121a). }\end{array}$ \\
\hline Protestant (share) & $\begin{array}{l}\text { Share of Protestants per total population in } 1890 \text { (Königliches Statistisches } \\
\text { Bureau in Berlin, 1861-1934, vol. 121a). }\end{array}$ \\
\hline $\begin{array}{l}\text { Non-German students } \\
\text { (share) }\end{array}$ & $\begin{array}{l}\text { Share of non-German-speaking students per total students of mandatory } \\
\text { school age, } 6-14 \text {, in } 1891 .\end{array}$ \\
\hline Linguistic polarization & $\begin{array}{l}\text { Linguistic polarization is measured through the polarization index as de- } \\
\text { scribed in Equation (4.1) and is based on the linguistic groups reported in the } \\
\text { education census in 1891: German, Polish, Kashubian, Lithuanian, Wendish, } \\
\text { Slavic, Danish, Frisian, Walloon, and "other" language. }\end{array}$ \\
\hline $\begin{array}{l}\text { Landownership concen- } \\
\text { tration }\end{array}$ & Interpolated. \\
\hline $\begin{array}{l}\text { Employed in manufac- } \\
\text { turing (share) }\end{array}$ & Interpolated. \\
\hline $\begin{array}{l}\text { Swing constituencies } \\
\text { (dummy) }\end{array}$ & $\begin{array}{l}\text { Variable takes value } 1 \text { if no party reached a share above } 50 \text { percent in the } \\
\text { first round of elections, } 0 \text { otherwise, in (Kaiserliches Statistisches Reichsamt, } \\
\text { 1872-1912). }\end{array}$ \\
\hline $\begin{array}{l}\text { Pro-nationalist delegate } \\
\text { (dummy) }\end{array}$ & $\begin{array}{l}\text { Variable takes value } 1 \text { if delegate belonged to the Free Conservative Party, } \\
\text { the German Conservative Party, or the National Liberal Party in Reichstag of } \\
\text { 1887, } 0 \text { otherwise (Kaiserliches Statistisches Reichsamt, 1872-1912). }\end{array}$ \\
\hline
\end{tabular}

Note: Unless otherwise specified, the data are from the Königliches Statistisches Bureau in Berlin (18611934, vol. 120). 
Table A3: 1896/1898 variables

\begin{tabular}{|l|l|}
\hline Voter turnout & $\begin{array}{l}\text { Number of votes divided by the electorate in 1898 (Kaiserliches Statistisches } \\
\text { Reichsamt, 1872-1918). }\end{array}$ \\
\hline $\begin{array}{l}\text { Pro-nationalist vote } \\
\text { (share) }\end{array}$ & $\begin{array}{l}\text { Sum of votes for the Free Conservative Party, the German Conservative } \\
\text { Party, and the National Liberal Party divided by the total number of valid } \\
\text { votes in 1898 (Kaiserliches Statistisches Reichsamt, 1872-1918). }\end{array}$ \\
\hline $\begin{array}{l}\text { Total spending per stu- } \\
\text { dent }\end{array}$ & $\begin{array}{l}\text { Total expenditures for public primary education per student of mandatory } \\
\text { school age, 6-14, in 1896. }\end{array}$ \\
\hline Central spending (share) & $\begin{array}{l}\text { Share of total expenditures for public primary education contributed by state } \\
\text { grants or funds in 1896. }\end{array}$ \\
\hline Urbanization rate & $\begin{array}{l}\text { Share of total population living in cities that held city rights in 1895 (Kö- } \\
\text { nigliches Statistisches Bureau in Berlin, 1861-1934, vol. 143). }\end{array}$ \\
\hline Population density & $\begin{array}{l}\text { Number of people per hectare in 1895 (Königliches Statistisches Bureau in } \\
\text { Berlin, 1861-1934, vol. 148a). }\end{array}$ \\
\hline Protestant (share) & $\begin{array}{l}\text { Share of Protestants per total population in 1895 (Königliches Statistisches } \\
\text { Bureau in Berlin, 1861-1934, vol. 148a). }\end{array}$ \\
\hline $\begin{array}{l}\text { Non-German students } \\
\text { (share) }\end{array}$ & $\begin{array}{l}\text { Share of non-German-speaking students per total students of mandatory } \\
\text { school age, 6-14, in 1896. }\end{array}$ \\
\hline Linguistic polarization & $\begin{array}{l}\text { Linguistic polarization is measured through the polarization index as de- } \\
\text { scribed in Equation (4.1) and is based on the linguistic groups reported in the } \\
\text { education census in 1896: German, Polish, Kashubian, Lithuanian, Wendish, } \\
\text { Slavic, Danish, Frisian, Walloon, and "other" language. }\end{array}$ \\
\hline $\begin{array}{l}\text { Pro-nationalist delegate } \\
\text { (dummy) }\end{array}$ & $\begin{array}{l}\text { Share of farms larger than 100 ha arable land 1895. (Königliches } \\
\text { Statistisches Bureau in Berlin, 1861-1934, vol. 142b). }\end{array}$ \\
\hline $\begin{array}{l}\text { Variable takes value 1 if delegate belonged to the Free Conservative Party, } \\
\text { tration }\end{array}$ & $\begin{array}{l}\text { Share of people employed in manufacturing (sector B) over total population } \\
\text { in 1895 (Kaiserliches Statistisches Reichsamt, 1872-1918, vol. 104 and 109). }\end{array}$ \\
\hline $\begin{array}{l}\text { Employed in manufach } \\
\text { turing (share) }\end{array}$ \\
\hline $\begin{array}{l}\text { Swing constituencies } \\
\text { (dummy) }\end{array}$
\end{tabular}

Note: Unless otherwise specified, the data are from the Königliches Statistisches Bureau in Berlin (18611934, vol. 151). 
Table A4: 1901/1903 variables

\begin{tabular}{|c|c|}
\hline Voter turnout & $\begin{array}{l}\text { Number of votes divided by the electorate in } 1903 \text { (Kaiserliches Statistisches } \\
\text { Reichsamt, 1872-1918). }\end{array}$ \\
\hline $\begin{array}{l}\text { Pro-nationalist vote } \\
\text { (share) }\end{array}$ & $\begin{array}{l}\text { Sum of votes for the Free Conservative Party, the German Conservative } \\
\text { Party, and the National Liberal Party divided by the total number of valid } \\
\text { votes in } 1903 \text { (Kaiserliches Statistisches Reichsamt, 1872-1918). }\end{array}$ \\
\hline $\begin{array}{l}\text { Total spending per stu- } \\
\text { dent }\end{array}$ & $\begin{array}{l}\text { Total expenditures for public primary education per student of mandatory } \\
\text { school age, } 6-14 \text {, in } 1901 .\end{array}$ \\
\hline Central spending (share) & $\begin{array}{l}\text { Share of total expenditures for public primary education contributed by state } \\
\text { grants or funds in } 1901 .\end{array}$ \\
\hline Urbanization rate & $\begin{array}{l}\text { Share of total population living in cities that held city rights in } 1900 \text { (Kö- } \\
\text { nigliches Statistisches Bureau in Berlin, 1861-1934, vol. 169). }\end{array}$ \\
\hline Population density & $\begin{array}{l}\text { Number of people per hectare in } 1900 \text { (Königliches Statistisches Bureau in } \\
\text { Berlin, 1861-1934, vol. 177). }\end{array}$ \\
\hline Protestant (share) & $\begin{array}{l}\text { Share of Protestants per total population in } 1900 \text { (Königliches Statistisches } \\
\text { Bureau in Berlin, 1861-1934, vol. 177). }\end{array}$ \\
\hline $\begin{array}{l}\text { Non-German students } \\
\text { (share) }\end{array}$ & $\begin{array}{l}\text { Share of non-German-speaking students per total students of mandatory } \\
\text { school age, } 6-14 \text {, in } 1901 .\end{array}$ \\
\hline Linguistic polarization & $\begin{array}{l}\text { Linguistic polarization is measured through the polarization index as de- } \\
\text { scribed in Equation (4.1) and is based on the linguistic groups reported in the } \\
\text { education census in 1901: German, Polish, Kashubian, Masurian, Lithuanian, } \\
\text { Moravian, Czech, Wendish, Slavic, Danish, and "other" language. }\end{array}$ \\
\hline $\begin{array}{l}\text { Landownership concen- } \\
\text { tration }\end{array}$ & Interpolated. \\
\hline $\begin{array}{l}\text { Employed in manufac- } \\
\text { turing (share) }\end{array}$ & Interpolated. \\
\hline $\begin{array}{l}\text { Swing constituencies } \\
\text { (dummy) }\end{array}$ & $\begin{array}{l}\text { Variable takes value } 1 \text { if no party reached a share above } 50 \text { percent in the } \\
\text { first round of elections, } 0 \text { otherwise, in } 1903 \text { (Kaiserliches Statistisches } \\
\text { Reichsamt, 1872-1918). }\end{array}$ \\
\hline $\begin{array}{l}\text { Pro-nationalist delegate } \\
\text { (dummy) }\end{array}$ & $\begin{array}{l}\text { Variable takes value } 1 \text { if delegate belonged to the Free Conservative Party, } \\
\text { the German Conservative Party, or the National Liberal Party in Reichstag of } \\
\text { 1898, } 0 \text { otherwise (Kaiserliches Statistisches Reichsamt, 1872-1918). }\end{array}$ \\
\hline
\end{tabular}

Note: Unless otherwise specified, the data are from the Königliches Statistisches Bureau in Berlin (18611934, vol. 176). 
Table A5: 1906/1907 variables

\begin{tabular}{|c|c|}
\hline Voter turnout & $\begin{array}{l}\text { Number of votes divided by the electorate in } 1907 \text { (Kaiserliches Statistisches } \\
\text { Reichsamt, 1872-1918, vol. 250). }\end{array}$ \\
\hline $\begin{array}{l}\text { Pro-nationalist vote } \\
\text { (share) }\end{array}$ & $\begin{array}{l}\text { Sum of votes for the Free Conservative Party, the German Conservative } \\
\text { Party, and the National Liberal Party divided by the total number of valid } \\
\text { votes in } 1907 \text { (Kaiserliches Statistisches Reichsamt, 1872-1918, vol. 250). }\end{array}$ \\
\hline $\begin{array}{l}\text { Total spending per stu- } \\
\text { dent }\end{array}$ & $\begin{array}{l}\text { Total expenditures for public primary education per student of mandatory } \\
\text { school age, } 6-14 \text {, in } 1906 .\end{array}$ \\
\hline Central spending (share) & $\begin{array}{l}\text { Share of total expenditures for public primary education contributed by state } \\
\text { grants or funds in } 1906 .\end{array}$ \\
\hline Urbanization rate & $\begin{array}{l}\text { Share of total population living in cities that held city rights in } 1905 \text { (Kö- } \\
\text { nigliches Statistisches Bureau in Berlin, 1861-1934, vol. 200). }\end{array}$ \\
\hline Population density & $\begin{array}{l}\text { Number of people per hectare in } 1905 \text { (Königliches Statistisches Bureau in } \\
\text { Berlin, 1861-1934, vol. 206a). }\end{array}$ \\
\hline Protestant (share) & $\begin{array}{l}\text { Share of Protestants per total population in } 1905 \text { (Königliches Statistisches } \\
\text { Bureau in Berlin, 1861-1934, vol. 206a). }\end{array}$ \\
\hline $\begin{array}{l}\text { Non-German students } \\
\text { (share) }\end{array}$ & $\begin{array}{l}\text { Share of non-German-speaking students per total students of mandatory } \\
\text { school age, } 6-14 \text {, in } 1906 .\end{array}$ \\
\hline Linguistic polarization & $\begin{array}{l}\text { Linguistic polarization is measured through the polarization index as de- } \\
\text { scribed in Equation (4.1) and is based on the linguistic groups reported in the } \\
\text { education census in 1906: German, Polish, Kashubian, Masurian, Lithuanian, } \\
\text { Moravian, Czech, Wendish, Slavic, Danish, and "other" language. }\end{array}$ \\
\hline $\begin{array}{l}\text { Landownership concen- } \\
\text { tration }\end{array}$ & $\begin{array}{l}\text { Share of farms larger than } 100 \text { ha arable land 1907. (Königliches } \\
\text { Statistisches Bureau in Berlin, 1861-1934). }\end{array}$ \\
\hline $\begin{array}{l}\text { Employed in manufac- } \\
\text { turing (share) }\end{array}$ & $\begin{array}{l}\text { Share of people employed in manufacturing (sector B) over total population } \\
\text { in } 1907 \text { (Kaiserliches Statistisches Reichsamt, 1872-1918, vol. } 204 \text { and 209). }\end{array}$ \\
\hline $\begin{array}{l}\text { Swing constituencies } \\
\text { (dummy) }\end{array}$ & $\begin{array}{l}\text { Variable takes value } 1 \text { if no party reached a share above } 50 \text { percent in the } \\
\text { first round of elections, } 0 \text { otherwise, in } 1907 \text { (Kaiserliches Statistisches } \\
\text { Reichsamt, 1872-1918, vol. 250). }\end{array}$ \\
\hline $\begin{array}{l}\text { Pro-nationalist delegate } \\
\text { (dummy) }\end{array}$ & $\begin{array}{l}\text { Variable takes value } 1 \text { if delegate belonged to the Free Conservative Party, } \\
\text { the German Conservative Party, or the National Liberal Party in Reichstag of } \\
\text { 1903, } 0 \text { otherwise (Kaiserliches Statistisches Reichsamt, 1872-1918, vol. 250). }\end{array}$ \\
\hline
\end{tabular}

Note: Unless otherwise specified, the data are from the Königliches Statistisches Bureau in Berlin (18611934, vol. 209). 
Table A6: 1911/1912 variables

\begin{tabular}{|c|c|}
\hline Voter turnout & $\begin{array}{l}\text { Number of votes divided by the electorate in } 1912 \text { (Kaiserliches Statistisches } \\
\text { Reichsamt, 1872-1918). }\end{array}$ \\
\hline $\begin{array}{l}\text { Pro-nationalist vote } \\
\text { (share) }\end{array}$ & $\begin{array}{l}\text { Sum of votes for the Free Conservative Party, the German Conservative } \\
\text { Party, and the National Liberal Party divided by the total number of valid } \\
\text { votes in } 1912 \text { (Kaiserliches Statistisches Reichsamt, 1872-1918). }\end{array}$ \\
\hline $\begin{array}{l}\text { Total spending per stu- } \\
\text { dent }\end{array}$ & $\begin{array}{l}\text { Total expenditures for public primary education per student of mandatory } \\
\text { school age, } 6-14 \text {, in } 1911 .\end{array}$ \\
\hline Central spending (share) & $\begin{array}{l}\text { Share of total expenditures for public primary education contributed by state } \\
\text { grants or funds in } 1911 .\end{array}$ \\
\hline Urbanization rate & $\begin{array}{l}\text { Share of total population living in cities that held city rights in } 1910 \text { (Kö- } \\
\text { nigliches Statistisches Bureau in Berlin, 1861-1934, vol. 200). }\end{array}$ \\
\hline Population density & $\begin{array}{l}\text { Number of people per hectare in } 1910 \text { (Königliches Statistisches Bureau in } \\
\text { Berlin, 1861-1934, vol. 206a). }\end{array}$ \\
\hline Protestant (share) & $\begin{array}{l}\text { Share of Protestants per total population in } 1910 \text { (Königliches Statistisches } \\
\text { Bureau in Berlin, 1861-1934, vol. 206a). }\end{array}$ \\
\hline $\begin{array}{l}\text { Non-German students } \\
\text { (share) }\end{array}$ & $\begin{array}{l}\text { Share of non-German-speaking students per total students of mandatory } \\
\text { school age, } 6-14 \text {, in } 1911 .\end{array}$ \\
\hline Linguistic polarization & $\begin{array}{l}\text { Linguistic polarization is measured through the polarization index as de- } \\
\text { scribed in Equation (4.1) and is based on the linguistic groups reported in the } \\
\text { education census in 1911: German, Polish, Kashubian, Czech, English, Hun- } \\
\text { garian, Italian, Slavic, Wendish, Lithuanian, Masurian, Swedish, Moravian, } \\
\text { Frisian, Danish, Dutch, French, and Walloon. }\end{array}$ \\
\hline $\begin{array}{l}\text { Landownership concen- } \\
\text { tration }\end{array}$ & Interpolated. \\
\hline $\begin{array}{l}\text { Employed in manufac- } \\
\text { turing (share) }\end{array}$ & Interpolated. \\
\hline $\begin{array}{l}\text { Swing constituencies } \\
\text { (dummy) }\end{array}$ & $\begin{array}{l}\text { Variable takes value } 1 \text { if no party reached a share above } 50 \text { percent in the } \\
\text { first round of elections, } 0 \text { otherwise, in } 1912 \text { (Kaiserliches Statistisches } \\
\text { Reichsamt, 1872-1918, vol. 250). }\end{array}$ \\
\hline $\begin{array}{l}\text { Pro-nationalist delegate } \\
\text { (dummy) }\end{array}$ & $\begin{array}{l}\text { Variable takes value } 1 \text { if delegate belonged to the Free Conservative Party, } \\
\text { the German Conservative Party, or the National Liberal Party in Reichstag of } \\
\text { 1907, } 0 \text { otherwise (Kaiserliches Statistisches Reichsamt, 1872-1918). }\end{array}$ \\
\hline
\end{tabular}

Note: Unless otherwise specified, the data are from the Königliches Statistisches Bureau in Berlin (18611934, vol. 231). 